ANA PAULA MACHADO DA SILVA

A CONCOMITÂNCIA DO FEMINICÍDIO COM QUALIFICADORAS SUBJETIVAS DO HOMICÍDIO SOB O PRISMA DA VEDAÇÃO AO BIS IN IDEM NO DIREITO PENAL BRASILEIRO 


\section{A CONCOMITÂNCIA DO FEMINICÍDIO COM QUALIFICADORAS SUBJETIVAS DO HOMICÍDIO SOB O PRISMA DA VEDAÇÃO AO BIS IN IDEM NO DIREITO PENAL BRASILEIRO}

Monografia apresentada ao Curso de Direito, da Universidade Luterana do Brasil, como requisito parcial para a obtenção do grau de Bacharel em Direito, sob orientação do Professor Especialista Ângelo Marcos Dorigo. Área de Concentração: Estado, Sociedade e Direito.

\section{CARAZINHO}




\title{
A CONCOMITÂNCIA DO FEMINICÍDIO COM QUALIFICADORAS SUBJETIVAS DO HOMICÍDIO SOB O PRISMA DA VEDAÇÃO AO BIS IN IDEM NO DIREITO PENAL BRASILEIRO
}

\begin{abstract}
Monografia de conclusão de curso apresentada no curso de Direito, da Universidade Luterana do Brasil, campus Carazinho, como requisito parcial para a obtenção do grau de Bacharel em Direito.
\end{abstract}

BANCA EXAMINADORA

Prof. Esp. Ângelo Marcos Dorigo

Presidente

Prof. Me. Luis Marcelo Mendes

Primeiro integrante 


\section{AGRADECIMENTOS}

Gratidão é o que resume este momento...

Agradeço:

Primeiramente a Deus, pois, apesar de todas as dificuldades que enfrentei até aqui, me manteve de pé, concedendo-me força, garra e coragem para prosseguir.

Ao meu pai (in memorian) que, apesar de ter convivido comigo por apenas 16 anos, me incentivou em todos os aspectos de minha vida, mesmo quando não havia expectativa alguma, devido nossas condições financeiras, de chegar onde estou. Obrigada meu amado pai.

De todo meu coração, a minha querida mãe, Rosane Machado da Silva, meu esteio, meu braço direito, mulher guerreira, de fibra, sem a qual eu não seria quem sou. Obrigada minha rainha.

Ao meu irmão Paulo Ricardo Machado da Silva, por quem tive forças de lutar e buscar o melhor para nossa família.

Ao meu namorado que, mesmo não tendo acompanhado toda minha trajetória acadêmica, esteve presente neste último um ano e meio, me apoiando e compreendendo. Obrigada pela paciência.

A minha melhor amiga, Aline Priori, que acompanhou todos os meus receios, inseguranças e sempre me motivou, fazendo com que eu acreditasse na minha capacidade.

A todos os professores que tive o privilégio de ter ao longo de minha jornada acadêmica, sendo eles, Ronaldo, Carlos, Liege, Daniele, Rosângela, Virgínia, Luis Marcelo e Omar, os quais admiro e tenho um carinho muito especial.

A minha querida Magda e ao meu amigo Alexandre por todo o apoio no decorrer do curso e, principalmente, nesta fase final.

Ao meu orientador Ângelo Marcos Dorigo que, juntamente com a professora Daniele Lima, foi de imensa importância para a consecução deste trabalho. Obrigada por toda seriedade, compromisso e competência.

Enfim, agradeço a todos que de alguma maneira contribuíram para que eu pudesse alcançar esse objetivo. 
Ao meu pai, Luiz Paulo Garcia da Silva, (in memoriam). 
"Não sou obrigado a vencer, mas tenho o dever de ser verdadeiro. Não sou obrigado a ter sucesso, mas tenho o dever de corresponder à luz que tenho."

(Abraham Lincoln). 


\section{RESUMO}

A presente pesquisa presta-se a analisar a concomitância do feminicídio com outras qualificadoras de natureza subjetiva do homicídio, a fim de verificar a (in) ocorrência do bis in idem. A abordagem seguiu o método dedutivo, ao passo que o método de procedimento adotado foi o monográfico histórico. Linha de pesquisa: Estado, Sociedade e Direito. Realizou-se uma abordagem histórica acerca da posição da mulher ao longo dos tempos, discorrendo acerca de seu tratamento perante a sociedade e a legislação. Verificaram-se os motivos que ensejaram a promulgação da Lei 11.340/06 e a ruptura, a partir desta, com o sistema anterior de tratamento à mulher vitimada pela violência doméstica e familiar ou pelas questões de gênero. Abordou-se o crime de homicídio, com ênfase no homicídio qualificado, a fim de se discorrer a respeito das qualificadoras subjetivas e objetivas deste delito. Por fim, tratou-se da qualificadora do feminicídio, com a demonstração dos motivos que o levaram à tipificação, a origem de sua terminologia, bem como apresentou-se a existência de quatro posicionamentos distintos quanto a sua natureza jurídica, com prevalência de que constitui qualificadora subjetiva e, portanto, incompatível ele de ser aplicado em concomitância com outra de igual natureza, sob pena de dupla punição do agente.

Palavras-chave: Feminicídio. Qualificadora de natureza subjetiva. Ne bis in idem. 


\begin{abstract}
The present research lends itself to analyzing the concomitance of femicide with other qualifiers of a subjective nature of homicide, in order to verify the (in) occurrence of the bis in idem. The approach followed the deductive method, while the procedure method adopted was the historical monograph. Research line: State, Society and Law. A historical approach has been made to the position of women over time, discussing their treatment of society and legislation. The motives behind the promulgation of Law 11.340 / 06 and the rupture from it with the previous system of treatment of women victims of domestic and family violence or of gender issues were verified. The crime of homicide was addressed, with emphasis on qualified homicide, in order to discuss the subjective and objective qualifiers of this crime. Finally, it was the feminicide qualifier, with the demonstration of the reasons that led to the typification, the origin of its terminology, as well as the existence of four distinct positions regarding its legal nature, with the prevalence of which constitutes Subjective qualifier and, therefore, incompatible it to be applied in concomitance with another of equal nature, under penalty of double punishment of the agent.
\end{abstract}

Keywords: Feminicide. Qualifier of a subjective nature. Ne bis in idem. 
1 INTRODUÇÃO

2 A MULHER COMO VÍTIMA DE VIOLÊNCIA ................................................ 11

2.1 Aspectos históricos da violência contra a mulher ..................................11

2.2 A Lei no 11.340/2006 e a ruptura com o anterior sistema .......................... 16

2.3 Formas de violência doméstica e familiar contra a mulher previstas na Lei Maria da Penha

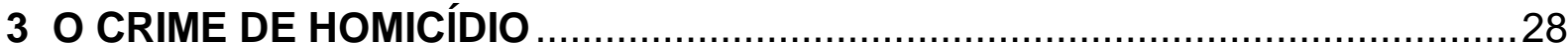

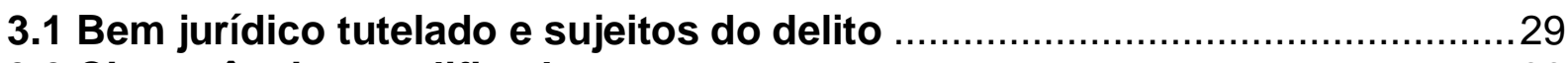

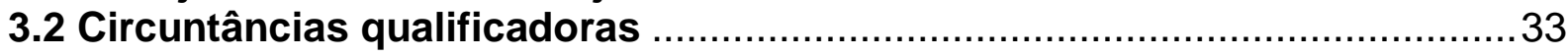

3.3 Competência para julgamento ……..................................................... 44

4 O FEMINICÍDIO NO CÓDIGO PENAL BRASILEIRO .......................................50

4.1 A punição do homicídio perpetrado contra a mulher antes da qualificadora do feminicídio e os motivos desta nova tipificação ..........................................5

4.2 Feminicídio: terminologia, conceito e previsão legal ..............................52

4.3 A concomitância do feminicídio com qualificadoras subjetivas do homicídio sob o prisma da vedação ao bis in idem no Direito penal brasileiro..................57

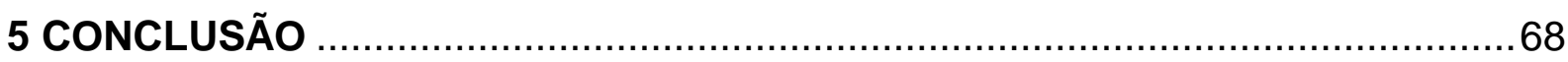

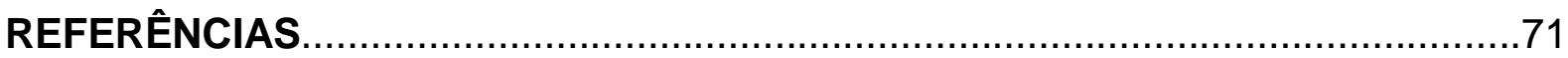




\section{INTRODUÇÃO}

O feminicídio, inovação recentemente incorporada ao Código Penal pela Lei no 13.104/15 como uma das qualificadoras do crime de homicídio, foi inserido na legislação brasileira com o intuito de atenuar e coibir com mais rigor os assassinatos decorrentes de violência doméstica e familiar contra a mulher ou discriminação ou menosprezo à condição do sexo feminino, que perduram há muito tempo na sociedade devido à cultura patriarcal nela enraizada.

A questão que ora se argui por meio desta pesquisa diz respeito à controvérsia existente no âmbito jurídico acerca da ocorrência, ou não, da violação do princípio ne bis in idem quando da concomitância desta qualificadora do homicídio com outras de natureza subjetiva.

Para tanto, o estudo em referência presta-se a analisar a natureza da qualificadora do feminicídio, pois, se subjetiva, haverá a incompatibilidade com demais qualificadoras desta mesma natureza, uma vez que a cumulação de ambas qualificadoras de ordem subjetiva implicaria na violação do ne bis in idem. Entretanto, se a natureza do feminicídio for considerada objetiva, não se cogitaria a dupla condenação pelo mesmo fato, pois qualificadoras subjetivas e objetivas poderiam subsistir em concomitância uma com a outra.

Destarte, objetiva-se mediante esse estudo indicar a natureza da qualificadora do feminicídio, se objetiva ou subjetiva, a fim de verificar a (in) ocorrência do bis in idem em relação às demais qualificadoras, subjetivas, do crime de homicídio.

Ressalta-se a relevância desta pesquisa, tendo em vista que se trata de matéria nova no âmbito do direito penal e a divergência acerca da natureza desta qualificadora está acarretando decisões não igualitárias e, consequentemente, condenações diversas a homicídios praticados sob as mesmas circunstâncias. Ademais não se pode deixar de sopesar o crescente número de assassinatos de mulheres por questão de gênero e em ambiente doméstico e familiar

Quanto aos aspectos metodológicos, a construção deste trabalho seguiu o método de abordagem dedutivo, o que se deu por meio de pesquisas em livros, periódicos, artigos, relatórios do governo, convenções, legislação e jurisprudência, sendo o método de procedimento o monográfico histórico. Já a linha de pesquisa recai sobre Estado, Sociedade e Direito. 
Para a conclusão deste estudo foi necessária a elaboração de três capítulos.

Primeiramente se realiza o estudo acerca dos aspectos históricos da mulher perante a sociedade e a legislação, verificando sua condição desde os primórdios da civilização até a ruptura desse sistema com o advento da Lei 11.340/06, momento em que se fará um panorama geral sobre as formas de violência doméstica e familiar previstas na referida lei.

O segundo capítulo aborda o crime de homicídio qualificado, verificando-se o bem jurídico tutelado pela norma e os sujeitos, ativo e passivo, bem como dissecando-se as qualificadoras subjetivas e objetivas deste delito, dentre as quais figura o feminicídio, e apreciando também a competência para o julgamento de tal infração penal.

Por fim, o terceiro e último capítulo expõe os aspectos relevantes da qualificadora do feminicídio, momento em que se vislumbrará como ocorria a punição dos homicídios praticados contra a mulher por razões de violência doméstica e familiar, ou por razões de gênero antes da tipificação do feminicídio, bem como qual foi a origem do termo feminicídio e a sua diferenciação do termo femicídio. Após, será apresentada a análise da previsão legal desta qualificadora perante a legislação penal brasileira. Encerra-se este capítulo com o ponto crucial da presente pesquisa, quais sejam os posicionamentos acerca da natureza da qualificadora do feminicídio, se subjetiva, objetiva ou outra, para que se possa averiguar a compatibilidade com outras qualificadoras do homicídio, principalmente de ordem subjetiva, a fim de se constatar se há, nestes casos, a (in) ocorrência de dupla condenação pelo mesmo fato (bis in idem).

Destarte, espera-se que a presente monografia contribua para a controvérsia que se apresenta diante da legislação penal brasileira a respeito da natureza da qualificadora do feminicídio, no intuito de que se resguarde o tratamento igualitário entre os acusados e se aprimore legislação tão relevante no combate à violência doméstica e familiar ou, unicamente, por questão de gênero contra a mulher. Ressalta-se que a determinação da natureza desta qualificadora é primordial para que se possam dirimir diversas dúvidas, dentre elas, a arguida nesta pesquisa. 


\section{A MULHER COMO VÍTIMA DE VIOLÊNCIA}

O presente capítulo visa realizar uma breve abordagem acerca da evolução histórica da mulher no plano social e jurídico, destacando os fatores que consagraram as inovações legislativas que ocorreram no Brasil, com ênfase na Lei 11.340/06, à qual será concedido enfoque especial, salientando os avanços que esta trouxe para a proteção da mulher, além das formas, nela previstas, de violência doméstica e familiar contra a mulher, como também os âmbitos em que ocorrem.

\subsection{Aspectos históricos da violência contra a mulher}

A violência contra a mulher existe desde os primórdios da civilização humana devido à desigualdade histórica entre os sexos, o que sempre colocou a mulher em posição de inferioridade em relação ao homem (MIRANDA, 2013).

Essa concepção de que a mulher é inferior e subordinada ao homem decorre, especialmente, da cultura patriarcal enraizada e subsistente na sociedade (DIAS, 2008).

A religião também contribuiu de maneira significativa para a ideia de subordinação da mulher, pois, de acordo com o texto mais importante da religião cristã, no livro "Gênesis", narra-se que Eva, a primeira mulher do mundo, foi criada a partir da costela de Adão, de forma que, segundo esta tese, a mulher nasceu dependente do homem e por esse motivo era considerada como uma propriedade deste e deveria servi-lo (LEITE; NORONHA, 2015).

Ainda sob o aspecto religioso, pode-se salientar que Eva foi considerada a responsável por cometer o primeiro de todos os pecados. Provocada pelo desejo e pela desobediência, Eva, no momento em que comeu o fruto proibido e o ofertou a Adão, transgrediu a norma imposta por Deus, de forma que foi castigada, conforme Gênesis 3:16: "E à mulher disse: Multiplicarei grandemente a tua dor, e a tua concepção; com dor darás à luz filhos; e o teu desejo será para o teu marido, e ele te dominará" (BÍBLIA ONLINE, 2016).

$\mathrm{Na}$ verdade, não é possível definir ao certo qual foi a causa exata para a desigualdade entre os sexos, que, durante longo período da história da civilização humana, existiu e ainda persiste em algumas situações. O que se pode afirmar é que sempre houve uma forte cultura de que a mulher servia, e serve, 
exclusivamente, para se dedicar ao lar e obedecer ao esposo, sendo vista na condição de propriedade do homem, bem como, de um ser sem vontade própria e inferior.

Leite e Noronha (2015) explicam que, nos tempos pretéritos, as mulheres não possuíam opções; eram criadas e preparadas para o casamento e deviam ser submissas aos esposos. Mesmo o marido agindo com a prática de violência contra a mulher, por uma questão de cunho social, o divórcio não era cogitado e sequer admitido pelas famílias, pois significava a desonra da mulher, de forma que elas se sentiam obrigadas a conviver com a realidade de agressões físicas, psicológicas, dentre outras.

\begin{abstract}
A mulher por muitos anos teve uma educação diferenciada da educação dada ao homem. A mulher era educada para servir, o homem era educado para assumir a posição de senhor todo poderoso. Quando solteira vivia sob a dominação do pai ou do irmão mais velho, ao casar-se, o pai transmitia todos os seus direitos ao marido, submetendo a mulher à autoridade deste. A mulher nada mais era do que um objeto (SILVA, [20--]a, s/p.).
\end{abstract}

Acrescenta Dias (2008) que o fundamento da violência doméstica é cultural e decorre da desigualdade no exercício do poder, que acarreta em uma relação, entre o homem e a mulher, de dominante e dominado, de modo que é possível afirmar que, desde que o mundo é mundo, a mulher sempre foi discriminada, desprezada, humilhada, coisificada, objetificada e monetarizada pelo homem.

Desta forma, é possível perceber que a mulher, desde a ideia de sua concepção no mundo, é vista como ser inferior, submissa ao homem, bem como, por longo período, diga-se de passagem até o advento da Lei 11.340/2006, não obteve a devida proteção legal, de acordo com o que se demonstrará a seguir.

No que tange ao tratamento da mulher, no ordenamento jurídico brasileiro, compreende-se que ela também se encontrava em esfera de inferioridade em relação ao homem, conforme se pode constatar pela análise da evolução histórica da legislação que se fará no decorrer deste capítulo.

Antes de o Brasil ter uma disposição de direito estabelecida, utilizavam-se, na Colônia, as ordenações do reino de Portugal, dentre as quais se podem destacar as Ordenações Filipinas, promulgadas no reinado de Felipe II, em 1603. Na era destas, que vigoraram até o ano de 1916, concedia-se ao homem o poder de matar a esposa e seu amante, em caso de adultério ou, até mesmo, em caso de suspeita 
da ocorrência deste (GAIA, 2010). A mulher traída, por sua vez, não possuía igual direito de modo que "as Ordenações Filipinas traziam em seu âmago o conservadorismo do poder patriarcal vivido na Idade Média" (SILVA, [20--]a, s. p.).

Com a promulgação do primeiro Código Penal brasileiro, no ano de 1830, a regra de que o marido tinha o direito de matar a esposa adúltera foi excluída. Já com a promulgação do Código Penal de 1890, passou-se a isentar a responsabilidade e, consequentemente, afastar a condenação criminal do marido traído (ELUF, 2003).

O Código posterior, de 1890, deixava de considerar crime o homicídio praticado sob um estado de total perturbação dos sentidos e da inteligência. Entendia que determinados estados emocionais, como aqueles gerados pela descoberta de adultério da mulher, seriam tão intensos que o marido poderia experimentar uma insanidade momentânea (ELUF, 2003, p.162).

$\mathrm{Na}$ década de 30, o renomado penalista e promotor público Roberto Lira iniciou sua luta contra a absolvição dos homicidas passionais, como eram denominados os maridos que assassinavam suas mulheres na época. Apesar de obter grandes triunfos contra esse tipo de delinquência encarada com benevolência pelos jurados, ainda assim, a tendência do Júri era a compreensão, devido à particularidade "perturbação dos sentidos e da inteligência" prevista pelo Código de 1890 (SILVA, 1997).

Somente com a promulgação do Código Penal de 1940 é que esta dirimente foi suprimida da legislação, sendo substituída pelo denominado homicídio privilegiado. A referida substituição representou uma grande evolução na esfera penal, no que tange à proteção da mulher, tendo em vista que atenuaria a impunidade existente, como leciona Eluf (2003, p. 162):

O Código Penal promulgado em 1940, ainda em vigor, eliminou a excludente de ilicitude referente à 'perturbação dos sentidos e da inteligência' que deixava impunes os assassinos chamados de passionais, substituindo a dirimente por uma nova categoria de delito, o 'homicídio privilegiado'. O passional não ficaria mais impune, apesar de receber uma pena menor que a atribuída ao homicídio simples (grifo do autor).

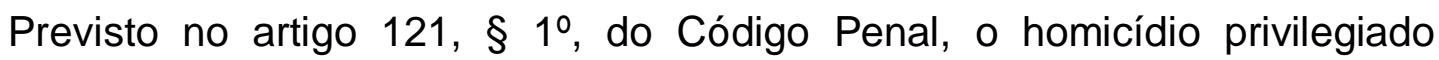
consiste em circunstâncias que diminuem a pena de um sexto a dois terços. Para que se configure o homicídio privilegiado, o agente deve cometer o crime impelido por motivo de relevante valor social ou moral, ou sob o domínio de violenta emoção, logo em seguida, a injusta provocação da vítima. 
Na realidade, o homicídio privilegiado não deixa de ser o homicídio previsto no tipo básico (caput); todavia, em virtude da presença de certas circunstâncias subjetivas que conduzem a menor reprovação social da conduta homicida, o legislador prevê uma causa especial de atenuação da pena (CAPEZ, 2015, p. 50).

As duas primeiras hipóteses de homicídio privilegiado dizem respeito aos motivos determinantes do crime. Inicialmente, tem-se o motivo de valor social, o qual, de acordo com os ensinamentos de Hungria (1976, p. 125), significa:

[...] aquele que corresponde, mais particularmente, aos interesses coletivos, ou é suscitado por específicas paixões ou preocupações sociais, nobres em si mesmas e condizentes com a atual organização da sociedade. Aquele que, num raptus de indignação cívica, mata um vil traidor da pátria, age, sem dúvida alguma, por motivo de relevante valor social (grifo do autor).

O segundo caso é o do homicídio praticado por relevante valor moral, que, consoante exemplifica Mirabete (2002, p. 67):

[...] diz respeito aos interesses individuais, particulares, do agente, entre eles os sentimentos de piedade e compaixão. Assim, o autor do homicídio praticado com o intuito de livrar um doente, irremediavelmente perdido, dos sofrimentos que o atormentam (eutanásia) goza de privilégio da atenuação da pena.

A última figura privilegiadora, frisa-se, na qual se buscava enquadrar os homicídios praticados pelos maridos contra suas mulheres, é aquela em que o delito é perpetrado sob violenta emoção logo em seguida a injusta provocação da vítima. Para a caracterização desta hipótese é necessária a presença de alguns requisitos, quais sejam, a existência de emoção violenta, injusta provocação da vítima e sucessão imediata entre a provocação e a reação (JESUS, 2001).

Cabe destacar que, com esta tipificação penal trazida no Código Penal de 1940, o homicida passional, ou seja, o marido traído, apesar de receber uma pena menor que a atribuída ao homicídio simples, não ficaria mais impune. Entretanto, a sociedade permanecia com a ideia de que o homem traído tinha o direito de matar a mulher (ELUF, 2003).

Pode-se dizer que o Código Penal promulgado em 1940 representou significativo avanço em relação à impunidade dos homicidas passionais, pois tornou mais difícil a absolvição dos homens que matavam suas esposas, uma vez que não 
havia mais a previsão de perturbação dos sentidos e da inteligência, que excluía a responsabilidade criminal do agente.

Ocorre que, apesar do Código Penal de 1940 prever a redução da pena para os homicídios caracterizados como privilegiados, os advogados de defesa da época não se conformavam com a nova previsão legal, já que, mesmo com apenamento mais brando, resultava na condenação de seus clientes. Diante disso, a defesa criou e começou a apresentar ao Tribunal do Júri, a tese de legítima defesa da honra e da dignidade, objetivando a absolvição de seus clientes (GAIA, 2010).

\begin{abstract}
Como essa solução não importava na liberdade imediata do réu - ele teria que cumprir uma pena, embora reduzida - é claro que os advogados procuraram encontrar outras formas capazes de fazer com que o Júri, respondendo aos quesitos, ou absolvesse, ou aplicasse uma pena ainda menor, que permitisse, por exemplo, a concessão do sursis, a suspensão condicional da pena. Daí ter surgido a alegação da 'legítima defesa da honra e da dignidade', que a sociedade algumas vezes admitia, porque quando o Código de 1940 entrou em vigor existiam, como ainda hoje existem, resíduos da concepção atrasada de que a infidelidade conjugal é um insulto, uma agressão ao cônjuge enganado. (SILVA, 1997, p. 197).
\end{abstract}

Mesmo não havendo a previsão legal da tese de legítima defesa da honra, uma vez que ela teria sido criada pelos advogados com a finalidade exclusiva de obterem resultados favoráveis a seus clientes, para o Tribunal do Júri, tribunal leigo que não tem compromissos legais ou doutrinários, a inexistência desta previsão era irrelevante, sendo que por muitas vezes a referida tese foi aceita, já que o julgamento dos jurados não se detém à lei e, sim, a suas consciências (SILVA, 1997).

Atualmente, devido à equiparação constitucionalmente assegurada entre homens e mulheres, proibindo-se todas as formas de discriminação, entende-se por inadmissível a tese de defesa da honra, já que essa reporta a mulher como um objeto, propriedade do homem, e não como um ser de direitos e vontades próprias que é (ELUF, 2003).

Salienta-se que, mesmo assim, a infidelidade conjugal é considerada um insulto, uma agressão ao cônjuge enganado, ocasionando, de parte de quem julga, sobretudo no interior, uma posição de simpatia em relação àquele que sofreu a traição, considerado ofendido, razão pela qual há uma inclinação dos jurados para atenuar a responsabilidade do homicida destes casos. Entretanto devido à mudança dos costumes, esta concepção vem sendo alterada sensivelmente, pois é 
absolutamente inaceitável qualquer ação violenta em consequência de ciúme ou de atitudes consideradas ofensivas de um cônjuge em relação ao outro. A solução civilizada é a separação (SILVA, 1997).

De qualquer forma, consigne-se que, por julgar o Júri utilizando-se de sua íntima convicção, ainda nos dias atuais, se pode constatar a adoção desta tese defendida nos plenários de julgamento.

Analisando a evolução histórica da mulher perante a sociedade e a legislação é possível perceber que, desde o princípio, foi ela discriminada, havendo a concepção de que era um ser inferior e submissa ao homem. Esta discriminação se estendia além do papel de objeto que the era imposto, atingindo, inclusive, a legislação, pois não possuía direitos iguais ao dos homens e, ainda, era permitido a estes dispor da vida da mulher em caso de traição ou até mesmo de suspeita. Apesar disso, verificando a legislação desde as Ordenações Filipinas até o Código Penal de 1940, é possível vislumbrar que, mesmo com toda desigualdade legal existente entre os sexos, grandes avanços foram sendo obtidos em relação à proteção à mulher, porém, a legislação mais relevante em relação à respectiva situação só veio a ser sancionada recentemente, após tratados e convenções assumidos pelo Brasil, conforme será abordado a seguir.

\subsection{A Lei no 11.340/2006 e a ruptura com o anterior sistema}

A criação e sancionamento da Lei ํo 11.340/06, denominada de Lei Maria da Penha, decorreu de uma longa trajetória de tratados internacionais ratificados pelo Brasil que visam o fim da violência à mulher, bem como possuem por finalidade atender o disposto no artigo 226, § 8으, da Constituição Federal, segundo o qual "o Estado assegurará a assistência à família na pessoa de cada um dos que a integram, criando mecanismos para coibir a violência no âmbito de suas relações" (LIMA, 2014).

Piovesan (2012) destaca que a partir da Declaração Universal de 1948 o Direito Internacional dos Direitos Humanos começa a se desenvolver mediante a adoção de inúmeros tratados internacionais voltados à proteção de direitos fundamentais, firmando, em âmbito global, o sistema especial de proteção a estes direitos. O processo de especificação genérica mostrava-se insuficiente, uma vez que tratava o indivíduo de forma geral e abstrata, sendo necessária a especificação 
do sujeito de direito, que passa a ser visto em suas peculiaridades e particularidades. Nesse sentido, as mulheres devem ser vistas nas especificidades de sua condição social.

O Direito Internacional dos Direitos Humanos deixa de examinar os seres humanos como sujeitos neutros, tidas suas diferenças em segundo plano, e passa a analisá-los em sua concretude. É o que se costuma denominar de processo de especificação do sujeito de direitos (SPIELER; MELO; CUNHA, 2013, p. 162).

Nesse contexto, por meio de pactos e convenções internacionais, se buscou responder determinadas violações de direitos humanos, dentre elas a discriminação e violência voltada, especificamente, contra a mulher.

No ano de 1975, a organização das Nações Unidas realizou, no México, a primeira Conferência Mundial da Mulher, proclamando a década das Nações Unidas para a Mulher, a qual se daria do ano 1975 até 1985. Impulsionada por esta convenção e com o objetivo de eliminar a discriminação e de assegurar a igualdade entre homens e mulheres, as Nações Unidas aprovaram, no ano de 1979, a Convenção sobre a Eliminação de todas as formas de Discriminação contra a Mulher (CEDAW), que veio a ser ratificada pelo Brasil no ano de 1984 (LIMA, 2014).

Recorda Dias (2008, p. 28) que "o comitê CEDAW apresentou algumas recomendações, dentre elas a de que os Estados participantes devem estabelecer legislação especial sobre violência doméstica e familiar contra a mulher".

Consoante 0 artigo $1^{\circ}$ da respectiva convenção, entende-se por discriminação contra a mulher toda distinção, exclusão ou restrição baseada no sexo e que tenha por objetivo ou resultado prejudicar ou anular o reconhecimento, gozo ou exercício pela mulher, independente de seu estado civil, com base na igualdade do homem e da mulher, dos direitos humanos e liberdades fundamentais nos campos político, econômico, social, cultural, civil ou em qualquer outro campo (CONVENÇÃO SOBRE A ELIMINAÇÃO DE TODAS AS FORMAS DE DISCRIMINAÇÃO CONTRA A MULHER, 1979).

Por sua vez, o artigo $2^{\circ}$ do referido regramento dispõe que os Estadospartes condenam a discriminação contra a mulher em todas as suas formas e assumem o compromisso de eliminá-la por todos os meios apropriados e sem dilações, bem como, adotando políticas pertinentes à concretização deste compromisso (CEDAW, 1979). 
Em 28 de junho de 2002, o Brasil ratificou o Protocolo Facultativo à Convenção sobre a Eliminação de todas as formas de Discriminação contra a Mulher adotado pela $43^{a}$ sessão da comissão do Status da Mulher da ONU, o que instituiu dois mecanismos de monitoramento, quais sejam, o da petição, que permite o encaminhamento de denúncias de violação de direitos enunciados na convenção à apreciação do comitê sobre a eliminação da discriminação contra a mulher, e o mecanismo de procedimento investigativo, que habilita tal comitê a investigar a existência de grave e sistemática violação aos direitos das mulheres (PIOVESAN, 2012).

Destaca-se, também, como grande avanço no cenário de proteção à mulher, a Convenção Interamericana para Prevenir, Punir e Erradicar a Violência contra a Mulher, denominada Convenção de Belém do Pará, cuja aprovação pela Assembleia Geral da Organização dos Estados Americanos OEA se operou no ano de 1994. Ratificada pelo Brasil no ano de 1995, a Convenção de Belém do Pará estabelece o dever dos Estados de condenar e eliminar a violência contra a mulher (SECRETARIA ESPECIAL DE POLÍTICA PARA AS MULHERES, 2006).

Nesse passo, além de esta convenção definir que a violência contra a mulher constitui uma violação aos direitos humanos, também determinou aos Estados a responsabilidade e o dever indelegável de erradicar e sancionar as situações de violência contra as mulheres, uma vez que estas possuem o direito de viver uma vida sem violência (BANDEIRA; ALMEIDA, 2015).

Uma das valiosas estratégias surgidas por meio da convenção é, nos termos de seu artigo 12, o mecanismo das petições à Comissão Interamericana de Direitos Humanos, o qual assegura a qualquer pessoa, grupo de pessoas ou entidade não governamental, a possibilidade de apresentar, à referida comissão, petições que contenham denúncias de violência perpetrada contra a mulher, desde que tenha havido o esgotamento prévio dos recursos internos, ou seja, desde que se tenha recorrido a todas as vias nacionais e elas tenham se demonstrado ineficazes, caso em que a comunidade internacional buscará responsabilizar o Estado violador, de forma a adotar medidas que restaurem ou reparem os direitos então violados (PIOVESAN, 2012).

Foi diante deste contexto que, ineditamente, o caso Maria da Penha provocou o sistema interamericano para a problemática da violência contra a mulher no Brasil. O país foi condenado no ano de 2001, em decorrência da denúncia 
apresentada em 1998 por Maria da Penha Fernandes, enviada conjuntamente pelo Centro de Justiça e Direito Internacional (Cejil) e pelo Comitê Latino-Americano de Defesa dos Direitos da Mulher (Cldem) (BANDEIRA; ALMEIDA, 2015).

\begin{abstract}
A denúncia alega a tolerância da República Federativa do Brasil (doravante denominada 'Brasil' ou 'o Estado') para com a violência cometida por Marco Antônio Heredia Viveiros em seu domićlio na cidade de Fortaleza, Estado do Ceará, contra a sua então esposa Maria da Penha Maia Fernandes durante os anos de convivência matrimonial, que culminou numa tentativa de homicídio e novas agressões em maio e junho de 1983. Maria da Penha, em decorrência dessas agressões, sofre de paraplegia irreversível e outras enfermidades desde esse ano. Denuncia-se a tolerância do Estado, por não haver efetivamente tomado por mais de 15 anos as medidas necessárias para processar e punir o agressor, apesar das denúncias efetuadas. Denuncia-se a violação dos artigos 1(1) (Obrigação de respeitar os direitos); 8 (Garantias judiciais); 24 (Igualdade perante a lei) e 25 (Proteção judicial) da Convenção Americana, em relação aos artigos II e XVIII da Declaração Americana dos Direitos e Deveres do Homem (doravante denominada 'a Declaração'), bem como dos artigos 3, 4,a,b,c,d,e,f,g, 5 e 7 da Convenção de Belém do Pará. A Comissão fez passar a petição pelos trâmites regulamentares. Uma vez que o Estado não apresentou comentários sobre a petição, apesar dos repetidos requerimentos da Comissão, os peticionários solicitaram que se presuma serem verdadeiros os fatos relatados na petição aplicando-se o artigo 42 do Regulamento da Comissão (COMISSÃO INTERAMERICANA DE DIREITOS HUMANOS, 2001, s/p).
\end{abstract}

A apresentação do caso à Comissão Interamericana de Direitos Humanos resultou no ano de 2001, após dezoito anos do cometimento do crime, na condenação do Estado brasileiro por negligência e omissão em relação à violência doméstica. Tal condenação culminou na recomendação do Estado brasileiro a concluir rápida e efetivamente o processo penal envolvendo o responsável pela agressão e tentativa de homicídio em prejuízo de Maria da Penha Fernandes, investigar séria e imparcialmente irregularidades e atrasos injustificados do processo penal, reparação e indenização civil à vítima decorrente da demora na prestação jurisdicional, sem prejuízo da ação de compensação contra o agressor (COMISSÃO INTERAMERICANA DE DIREITOS HUMANOS, 2001).

Além destas recomendações para o caso específico de Maria da Penha Fernandes, a Comissão ainda recomendou que o Brasil prosseguisse e intensificasse o processo de reforma para evitar a tolerância estatal e o tratamento discriminatório com respeito à violência doméstica contra mulheres (COMISSÃO INTERAMERICANA DE DIREITOS HUMANOS, 2001). 
No campo jurídico a omissão do Estado brasileiro afrontava a Convenção Interamericana para Prevenir, Punir e Erradicar a Violência contra a Mulher - a 'Convenção de Belém do Pará' - ratificada pelo Brasil em 1995. É dever do Estado brasileiro implementar políticas públicas destinadas a prevenir, punir e a erradicar a violência contra a mulher, em consonância com os parâmetros internacionais e constitucionais, rompendo com o perverso ciclo de violência que, banalizado e legitimado, subtraia a vida de metade da população brasileira. Tal omissão deu ensejo à condenação sofrida pelo Brasil no caso Maria da Penha (PIOVESAN, 2012, p. 200).

Desta forma, em 31 de outubro de 2002, finalmente, houve a prisão do agressor de Maria da Penha Fernandes, encerrando o ciclo de impunidade que perdurava por dezenove anos.

À luz deste cenário, o caso Maria da Penha permitiu, de forma emblemática, romper com a invisibilidade e a impunidade das agressões ocorridas em âmbito doméstico e familiar contra a mulher, tendo representado fator determinante para que as mulheres pudessem ter um tratamento diferenciado perante a legislação penal brasileira.

Importante salientar que até o advento da Lei Maria da Penha, no ano de 2006, o Brasil não dispunha de legislação específica para tratar a respeito da violência contra a mulher, sendo aplicada, para grande parte dos delitos, a Lei no 9.099/95, que instituiu os Juizados Especiais Criminais, o qual abrange, especificamente, as infrações penais de menor potencial ofensivo. Contudo, a violência contra a mulher não podia ser, equivocadamente, considerada e tratada como infração penal de menor potencial ofensivo e, sim, devia ser vista como a grave violação de direitos humanos que, de fato é, motivo pelo qual a aplicação da Lei no 9.099/95 era absolutamente insatisfatória (PIOVESAN, 2012).

Mesmo com as significativas mudanças ocorridas no Código Penal a partir do ano de 2004, como por exemplo, a tipificação de violência doméstica acrescentada ao artigo 129 do Código Penal e a alteração de artigos discriminatórios, avanços derivados das recomendações do Comitê da Convenção para a Eliminação de todas as Formas de Discriminação contra as Mulheres (CEDAW) contidas no Relatório Nacional brasileiro de 2003, havia a existência de um conflito legislativo entre a Convenção de Belém do Pará e a Lei oㅜ 9.099/95, o que mantinha no Brasil um padrão de quase descriminalização dos crimes praticados contra as mulheres no âmbito das relações familiares (BARSTED; PITANGUY, 2011). 
A Convenção e um conjunto de outros instrumentos internacionais consideraram a violência contra a mulher uma violação de direitos humanos, ou seja, um crime de grande gravidade. A Lei 9.099/95 trata de crimes considerados de menor potencial ofensivo e para julgá-los foram criados procedimentos processuais penais, com forte influência da legislação processual civil, a serem aplicados por Juizados Especiais Criminais (BARSTED; PITANGUY, 2011, p. 358).

Havia, pois, uma inconsistência entre a grandeza do delito violência contra a mulher, reconhecida internacionalmente como uma afronta aos direitos humanos, e a lei que lhe era aplicada, que tratava de crimes de menor potencial ofensivo.

Ressalta-se que o Comitê CEDAW, apesar de reconhecer os esforços realizados pelo Brasil para fazer frente à violência contra a mulher, revelou preocupação pela persistência dessa agressão e pela indulgência em relação aos autores desses atos de violência, motivo pelo qual recomendou que o país elaborasse, imediatamente, uma lei que versasse sobre violência doméstica contra as mulheres e tomasse medidas práticas para acompanhar de perto e supervisionar a aplicação desta lei e sua eficácia (BARSTED; PITANGUY, 2011).

Dias (2008) explica que os avanços na legislação antes da Lei no 11.340/06 foram tímidos, fazendo referência à Lei no 10.455/02, a qual passou a admitir a possibilidade, na hipótese de violência doméstica, de o juiz decretar o afastamento do agressor do lar conjugal, e também a Lei n 10.886/04, que acrescentou um subtipo à lesão corporal leve, decorrente de violência doméstica, aumentando a pena mínima de três para seis meses de detenção. ${ }^{1}$

Com a agravação da pena mínima de detenção, de 3 para 6 meses, não ficaria afastada a aplicação da transação penal (art. 76 da Lei n. 9.099/95) nem o sursis processual (art. 89 da mesma lei), sendo cabíveis as penas restritivas de direitos (art. 44 do $\mathrm{CP}$ ). Quanto à ação penal, tratando-se de lesão corporal leve (§ $\left.9^{\circ}\right)$, a iniciativa da autoridade policial e do Ministério Público dependia da representação da ofendida (art. 88 da Lei dos Juizados Especiais Criminais). Somente na hipótese de lesão corporal grave, gravíssima ou seguida de morte (art. 129, §§ 1으. $2^{\circ}$ e $3^{\circ}$ ), praticada em qualquer das circunstâncias definidoras da violência doméstica contra a mulher (§ 9), a ação penal era pública incondicionada (JESUS, 2010, p. $51)$.

Ocorre que nenhuma das mudanças foi eficaz à problemática da violência doméstica e familiar contra a mulher, pois a questão ainda continuava a tramitar no

\footnotetext{
${ }^{1}$ Registre-se, porém, que com o advento da Lei no 11.340/06 a pena mínima em tal situação voltou a ser estabelecida em três meses, conforme hoje constante no artigo 129, §9, do Código Penal.
} 
Juizado Especial Criminal e sob a incidência dos institutos despenalizadores da Lei 9.009/95, o que tornava as inovações legislativas insatisfatórias e frustradas na resolução do enfrentamento da violência em questão (DIAS, 2008).

Finalmente, em 7 de agosto de 2006, ingressou no sistema jurídico brasileiro a Lei n. 11.340, determinando mecanismos para coibir e prevenir a violência doméstica e familiar contra a mulher, nos termos do artigo 226 , $\S 8^{\circ}$, da Constituição Federal, bem como decorrente da Convenção sobre a Eliminação de Todas as Formas de Violência contra a Mulher, da Convenção Interamericana para Prevenir, Punir e Erradicar a Violência contra a Mulher e de outros tratados internacionais ratificados pelo Brasil, estabelecendo medidas para a prevenção, assistência e proteção às mulheres em situação de violência (PIOVESAN, 2012).

Com o advento da denominada Lei Maria da Penha, houve o rompimento com o sistema anterior em relação ao tratamento dos casos de violência doméstica e familiar contra a mulher, culminando em inovações extraordinárias.

Dentre as inovações trazidas pela Lei ํo 11.340/06, pode-se destacar a prevista no artigo $6^{\circ}$ que reconhece a violência doméstica e familiar contra a mulher como uma das formas de violação dos direitos humanos, não podendo, de acordo com artigo 41, bem como a Súmula 536 do Superior Tribunal de Justiça, ser tratada como uma infração de menor potencial ofensivo, sendo, por conseguinte, expressamente vedada a aplicação da Lei n. 9.009/95 (BRASIL, 2016a);(BRASIL, 2016b).

Igualmente, uma das grandes novidades da referida legislação foi, conforme previsto no artigo 14, a criação dos Juizados de Violência Doméstica e Familiar contra a Mulher, com competência cível e criminal, bem como, o atendimento policial especializado para as mulheres, em particular nas Delegacias de Atendimento à Mulher, disposto no inciso IV do artigo 8 (BRASIL, 2016a).

Ademais, o referido diploma legal dispõe em seu artigo 19 sobre a possibilidade de o juiz, a requerimento do Ministério Público ou a pedido da ofendida, conceder medidas protetivas de urgência, as quais são exemplificativamente previstas nos artigos 22 e 23 da lei em comento (BRASIL, 2016a).

Como visto, a Lei ำ 11.340/06 acarretou um grande avanço perante a violência doméstica e familiar contra a mulher, concedendo o devido tratamento a este problema que há muito tempo padecia de uma atenção especial. Diante desta 
óptica, relevante se faz adentrar nas formas de violências que estão previstas na legislação especial em questão, as quais acometem mulheres diariamente.

\subsection{Formas de violência doméstica e familiar contra a mulher previstas na Lei Maria da Penha}

De acordo com o expresso no artigo $5^{0}$ da Lei $\mathrm{n}^{0}$ 11.340/06, configura violência doméstica e familiar contra a mulher qualquer ação ou omissão baseada no gênero que lhe cause morte, lesão, sofrimento físico, sexual ou psicológico e dano moral ou patrimonial, no âmbito da unidade doméstica, no âmbito da família ou em qualquer relação íntima de afeto (BRASIL, 2016a).

Desta forma, antes de enfrentar as formas de violência propriamente ditas, se faz relevante a análise dos âmbitos em que ela ocorre, registrando-se, por oportuno que, no polo ativo, pode figurar qualquer pessoa, bastando estar caracterizado o vínculo de relação doméstica, de relação familiar ou afetividade (DIAS, 2008).

Importante destacar que a proteção contemplada pela Lei Maria da Penha terá incidência apenas quando a violência contra a mulher for executada em tais situações de vulnerabilidade, não se estendendo a proteção se a violência não tiver sido executada no ambiente doméstico, familiar ou de qualquer relação de afeto (LIMA, 2014).

O inciso I, do artigo 5ำ da lei em comento expressa a primeira situação de possibilidade de ocorrência da violência doméstica ou familiar contra a mulher, o âmbito da unidade doméstica, compreendido como o espaço de convívio permanente de pessoas, com ou sem vínculo familiar, inclusive as esporadicamente agregadas (BRASIL, 2016a).

Nesse sentido dispõe Cunha (2007, p. 30):

Agressão no âmbito da unidade doméstica compreende aquela praticada no espaço caseiro, envolvendo pessoas com ou sem vínculo familiar, inclusive as esporadicamente agregadas, integrantes dessa aliança (insere-se, na hipótese, a agressão do patrão em face da empregada).

O inciso II, do artigo 5ำ da Lei no 11.340/06 prevê a segunda hipótese de reconhecimento da violência doméstica e familiar contra a mulher, que ocorre 
quando a agressão é cometida no âmbito da família, compreendida como a comunidade formada por indivíduos que são ou se consideram aparentados, unidos por laços naturais, por afinidade ou por vontade expressa (BRASIL, 2016a).

\begin{abstract}
Ao contrário da hipótese anterior, o traço peculiar dessa hipótese de violência é a existência de vínculos familiares, pouco importando o local de cometimento da violência, que não necessariamente precisa ser o espaço caseiro. Em outras palavras, havendo laços familiares entre agressor e vítima, pouco importa se a violência foi praticada no âmbito da unidade doméstica ou em qualquer outro ambiente. A violência familiar contra a mulher estará caracterizada em ambas as hipóteses, independentemente de coabitação entre o agente e a ofendida. (LIMA, 2014, p. 12).
\end{abstract}

Já 0 inciso III, do artigo $5^{\circ}$ da Lei Maria da Penha refere-se à última disposição que caracteriza a Lei 11.340/06, sendo ela qualquer relação íntima de afeto, na qual o agressor conviva ou tenha convivido com a ofendida, independente de coabitação (BRASIL, 2016a).

Para Nucci (2014, p. 608), a relação íntima de afeto "é o relacionamento estreito entre duas pessoas, fundamentado em amizade, amor, simpatia, dentre outros sentimentos de aproximação". O autor complementa referindo que relações íntimas de afeto são aquelas em que o agressor convive ou conviveu com a ofendida, ainda que nunca tenha coabitado com ela.

Identificadas as situações em que se presume a maior vulnerabilidade da mulher, nas quais as agressões compreendidas pela Lei Maria da Penha ocorrem, passa-se a discorrer a respeito das formas de violência que acometem as vítimas mulheres.

O legislador especificou as formas de violência doméstica e familiar contra a mulher, de maneira não exaustiva, no artigo $7^{\circ}$ da Lei 11.340/06.

Iniciando o rol não taxativo das formas de violência doméstica e familiar contra a mulher, no inciso I, do referido artigo de lei, está prevista a violência física, a qual, de acordo com o enunciado do próprio inciso, significa qualquer conduta que ofenda a integridade física ou saúde corporal da mulher (BRASIL, 2016a).

Cunha (2007, p. 37) define violência física como sendo:

[...] o uso da força, mediante socos, tapas, pontapés, empurrões, arremesso de objetos, queimaduras etc, visando, desse modo, ofender a integridade ou a saúde corporal da vítima, deixando ou não marcas aparentes, naquilo que se denomina, tradicionalmente, vis corporalis (grifo do autor). 
Prevista no inciso II, do artigo $7^{0}$ da lei em apreço, a violência psicológica é entendida como qualquer conduta que cause dano emocional e diminuição da autoestima, que prejudique e perturbe o pleno desenvolvimento, ou que vise degradar ou controlar suas ações, comportamentos, crenças e decisões, mediante ameaça, constrangimento, humilhação, manipulação, isolamento, vigilância constante, perseguição contumaz, insulto, chantagem, ridicularização, exploração e limitação do direito de ir e vir ou qualquer outro meio que lhe cause prejuízo à saúde psicológica e à autodeterminação (BRASIL, 2016a).

Lima (2014) ressalta que a violência psicológica pode, por vezes, ser mais grave que a própria violência física, pois o agressor procura causar danos emocionais à mulher, o que é feito geralmente por meio de ameaças, rejeições, humilhações ou discriminações, com o objetivo de diminuir a autoestima e prejudicar o pleno desenvolvimento da vítima. Como exemplo, pode-se citar crimes como o constrangimento ilegal (artigo 146 Código Penal), a ameaça (artigo 147 do Código Penal) e o sequestro e cárcere privado (artigo 148 do Código Penal).

A violência sexual, prevista no inciso III, do artigo 7ํㅜ da Lei nำ 11.340/06, também é uma das formas de violência previstas pela Lei Maria da Penha e corresponde a qualquer conduta que constranja a mulher a presenciar, a manter ou a participar de relação sexual não desejada, mediante intimidação, ameaça, coação ou uso da força; que induza a comercializar ou a utilizar, de qualquer modo, a sua sexualidade, que a impeça de usar qualquer método contraceptivo ou que a force ao matrimônio, à gravidez, ao aborto ou à prostituição, mediante coação, chantagem, suborno ou manipulação; ou que limite ou anule o exercício de seus direitos sexuais e reprodutivos (BRASIL, 2016a).

Os delitos equivocadamente chamados de 'contra os costumes', constituem,
às claras, violência sexual. Quem obriga uma mulher a manter relação
sexual não desejada pratica o crime sexual de estupro. Também os outros
crimes contra a liberdade sexual configuram violência sexual quando
praticados contra a mulher: atentado violento ao pudor, posse sexual
mediante fraude, atentado ao pudor mediante fraude, assédio sexual e
corrupção de menores (DIAS, 2008, p. 49).

Outra forma de violência prevista pela lei em questão é a patrimonial (artigo $7^{\circ}$, inciso IV), entendida como qualquer conduta que configure retenção, subtração, destruição parcial ou total de seus objetos, instrumentos de trabalho, documentos 
pessoais, bens, valores e direitos ou recursos econômicos, incluindo os destinados a satisfazer suas necessidades (BRASIL, 2016a).

\begin{abstract}
Apesar de o legislador fazer referência à violência patrimonial, esta forma de violência doméstica e familiar contra a mulher prevista no art. $7^{\circ}$, IV, da Lei Maria da Penha, não pressupõe o emprego de violência física ou corporal, restando caracterizada mesmo nas hipóteses de crimes patrimoniais praticados sem o emprego de vis corporalis ou grave ameça (v.g., furto, furto de coisa comum, apropriação indébita, estelionato) (LIMA, 2014, p. 26, grifo do autor).
\end{abstract}

São exemplos de crimes que materializam essa forma de violência os delitos descritos no Título II da Parte Especial do Código Penal, quais sejam, os crimes contra o patrimônio.

É importante destacar que, a partir da definição de violência doméstica concedida pela Lei Maria da Penha, não se aplicam as imunidades absolutas ou relativas contidas nos artigos 181 e 182 do Código Penal, referentes aos crimes contra o patrimônio, quando a vítima é mulher e mantém com o autor do crime vínculo de natureza familiar (DIAS, 2008).

A última forma de violência doméstica e familiar contra a mulher prevista no rol exemplificativo do artigo $7^{0}$ é a moral, expressa no inciso $\mathrm{V}$, constitui qualquer conduta que configure calúnia, difamação ou injúria (BRASIL, 2016a).

Acrescenta-se que violência verbal, entendida como a conduta que consista em calúnia (imputar à vítima a prática de determinado fato criminoso sabidamente falso), difamação (imputar à vítima a prática de determinado fato desonroso) ou injúria (atribuir à vítima qualidades negativas) normalmente se dá concomitantemente à violência psicológica (CUNHA, 2007, p. 38).

A Lei 11.340/06 completou, no mês de agosto do corrente ano, uma década. Há 10 anos rompia-se com o anterior sistema que não estendia à mulher a proteção necessária e tampouco era eficaz na punição dos agressores. Enfim, apesar desta lei ainda não possuir os mecanismos eficientes para atingir integralmente seus objetivos, comparando-a com o histórico de tratamento da mulher perante a legislação penal, afirma-se que foi um grande passo a caminho do resguardo dos direitos humanos.

Devido à violência doméstica e familiar contra a mulher ser o trajeto, muitas vezes, para a consecução da violência mais extrema, que é a morte, o homicídio perpetrado contra a mulher por estas circunstâncias consistirá em homicídio 
qualificado, inovação trazida pela Lei 13.104/15. Além da hipótese referida, também será qualificado o homicídio praticado por razões de menosprezo ou discriminação à condição de mulher. Diante disso, se faz necessário discorrer acerca do crime de homicídio qualificado, crime esse em que está previsto o feminicídio que qualifica as citadas condutas delituosas praticadas contra a mulher, o que se fará no próximo capítulo. 


\section{O CRIME DE HOMICÍDIO}

Considerando que o tema central em estudo versa sobre uma das qualificadoras do delito de homicídio, adequado que se façam considerações acerca do tipo penal em questão, a fim de que se possa obter um melhor entendimento no momento da abordagem do feminicídio.

Tipificado no artigo 121 do Código Penal, o "homicídio é a morte de um ser humano provocada por outro ser humano. É a eliminação da vida de uma pessoa praticada por outra. O homicídio é o crime por excelência" (CAPEZ, 2015, p. 22).

Para corroborar com a conceituação de homicídio, relevante se faz destacar a clássica definição de Hungria (1976, p. 25):

\footnotetext{
O homicídio é o tipo central de crimes contra a vida e é o ponto culminante na ortografia dos crimes. É o crime por excelência. É o padrão da delinquência violenta ou sanguinária, que representa como que uma reversão atávica às eras primevas, em que a luta pela vida, presumivelmente, se operava com o uso normal dos meios brutais e animalescos. É a mais chocante violação do senso moral médio da humanidade civilizada (grifo do autor).
}

De acordo com Greco (2009), de todas as infrações penais, o homicídio é aquele que, efetivamente, desperta mais interesse, pois reúne uma mistura de sentimentos que o torna diferente dos demais. Acrescenta-se que, normalmente, o homicida é autor de um único crime, do qual, na maioria dos casos, se arrepende, porém, existem criminosos frios, que sentem prazer ao ver o sofrimento da vítima.

Independente do tipo de homicida, seja o que se arrepende ou o que mata por prazer, certo é que o homicídio é um dos crimes mais repugnantes existentes na sociedade, pois consiste em ceifar o bem mais precioso de todos, a vida.

Diante deste contexto será realizada, neste capítulo, uma abordagem geral sobre este delito, destacando pontos relevantes como o bem jurídico tutelado, sujeitos do crime, qualificadoras e a competência para o seu julgamento. Tais apontamentos são de suma importância, pois, no momento oportuno, virão a agregar no assunto principal a ser debatido. 


\subsection{Bem jurídico tutelado e sujeitos do delito}

O homicídio consiste na destruição da vida humana, que não é nada menos do que o mais valioso bem jurídico tutelado, sendo que, conforme leciona Mirabete (2002, p. 62), "tem a vida a primazia entre os bens jurídicos, sendo indispensável à existência de todo direito individual porque "sem ela não há personalidade e sem esta não há cogitar de direito individual'”' (grifo do autor).

Dentre os bens jurídicos de que o indivíduo é titular e para cuja proteção a ordem jurídica vai ao extremo de utilizar a própria repressão penal, a vida destaca-se como o mais valioso. A conservação da pessoa humana, que é a base de tudo, tem como condição primeira a vida, que, mais que um direito, é a condição básica de todo direito individual (BITENCOURT, 2015, p. 52, grifo do autor).

O bem jurídico vida humana é tão relevante que sua proteção constitui um imperativo de ordem constitucional. O artigo 5ㅇ, caput, da Constituição Federal estabelece que "todos são iguais perante a lei, sem distinção de qualquer natureza, garantindo-se aos brasileiros e aos estrangeiros residentes no País a inviolabilidade do direito à vida, à liberdade, à igualdade, à segurança e à propriedade" (BRASIL, 2016c, grifo nosso).

É possível destacar que a vida pressupõe uma extraordinária importância, pois é a base de todos os direitos fundamentais da pessoa humana, de modo que todos os indivíduos possuem o direito à sua proteção, tanto em relação aos abusos do Estado como, principalmente, dos particulares em geral.

Apesar de a proteção à vida ser um direito privado, fazendo parte dos direitos constitutivos da personalidade, o indivíduo não pode dela livremente dispor, conforme ensina Hungria (1976, p. 227):

\footnotetext{
A vida não é um bem que se aceite ou se abandone ad libitum. Só se pode renunciar o que se possui, e não também o que se é. O direito de viver não é um direito sobre a vida, mas à vida, no sentido de correlativo da obrigação de que os outros homens respeitem nossa vida. E não podemos renunciar o direito à vida, porque a vida cada homem diz com a própria existência da sociedade e representa uma função social (grifo do autor).
}

Ainda, embora a lei maior tenha assegurado o direito à vida, ele não é absoluto, tendo em vista que, apesar da Constituição Federal da República vedar a pena de morte, como forma de limitar os abusos do Estado, em seu artigo $5^{\circ}$, inciso 
XLVII, alínea a, traz uma exceção a esta regra, remetendo ao artigo 84, inciso XIX, ou seja, nos casos de guerra declarada, a pena de morte pode ser instituída (BRASIL, 2016c).

Nesse norte, pode-se dizer que o direito à vida é relativo, visto que, além da exceção referente à pena de morte trazida pelo texto constitucional, há a existência das excludentes de ilicitude no ordenamento jurídico, pelas quais a conduta do agente que elimina a vida de outro pode ser justificada, por exemplo, pelo estado de necessidade ou legítima defesa.

Apesar destas exceções suportadas pelo Direito, a vida é enfaticamente protegida pela Constituição Federal e pela legislação penal, de modo a tentar afastar o máximo a ocorrência do crime de homicídio.

O homicídio constitui-se em crime comum e, como todo delito, tem um agente cometedor da conduta e um alguém que, na condição de vítima, sofre as consequências da ação ou omissão, sendo que esses são considerados sujeitos ativos e passivos da infração penal. Nesse trilhar, o homicídio pode ser cometido e ter como vítima qualquer pessoa, não havendo uma condição especial para figurar como sujeito passivo ou ativo desta infração penal.

Considera-se sujeito ativo do crime de homicídio o ser humano que pratica a figura típica descrita na lei, mais precisamente no artigo 121 do Código Penal. Este conceito abrange tanto o agente que pratica o verbo nuclear do tipo, ou seja, aquele que desenvolve a conduta de matar, como aquele que por ventura concorrer para a produção do resultado, o chamado partícipe (CAPEZ, 2015).

Bitencourt (2015, p. 54) ressalta que "sujeito ativo do crime de homicídio pode ser qualquer pessoa, pois, em se tratando de crime comum, não requer nenhuma condição particular" (grifo do autor).

Em se tratando do sujeito passivo do delito de homicídio, isto é, aquele que é o titular do bem jurídico lesado ou ameaçado, de regra, assim como o sujeito ativo, não requer nenhuma qualidade especial, podendo ser qualquer ser humano sem distinção de idade, sexo, raça, condição social (MIRABETE, 2002). 
Sujeito passivo do homicídio é alguém, isto é, qualquer pessoa humana, o 'ser vivo nascido de mulher', i'uomo vivo, qualquer que seja sua condição de vida, se saúde, ou de posição social, raça, religião, nacionalidade, estado civil, idade, convicção política ou status penalis. Criança ou adulto, pobre ou rico, letrado ou analfabeto, nacional ou estrangeiro, branco ou amarelo, silvícola ou civilizado - toda criatura humana, com vida, pode ser sujeito passivo do homicídio, pois qualquer ser humano é reconhecido o direito à vida que a lei penalmente tutela. O moribundo tem direito a viver os poucos instantes que lhe restam de existência terrena, e, por isso, pode ser sujeito passivo do homicídio. Assim também o condenado à morte. Indiferente é, por outro lado, que a vítima tenha sido, ou não, identificada (MARQUES, 1977, p. 77 apud CAPEZ, 2015, p. 31, grifo do autor).

Diante da presente abordagem, relevante se faz discorrer propriamente a respeito dos sujeitos do crime de feminicídio, objeto central do estudo em questão, tendo em vista que, diferentemente dos crimes de homicídio em geral, este requer uma qualidade especial para figurar no polo passivo.

Primeiramente, não há nenhuma qualidade específica exigida para que se figure como agente ativo do crime de feminicídio, podendo este ser praticado por qualquer pessoa, desde que o cometa devido as razões expressas no artigo 121, $\S$ $2^{\circ}$, VI do Código Penal, especificadas no $\S 2$ - A do referido dispositivo legal (DELMANTO et al., 2016)

\footnotetext{
Admite-se que o sujeito ativo seja tanto homem quanto mulher, bastando a existência de relação familiar ou de afetividade, não importando o gênero do agressor, já que a norma visa tão somente à repressão e prevenção da violência doméstica contra a mulher. (CUNHA, 2016, p. 65).
}

Apesar de qualquer pessoa poder ser sujeito ativo no crime de feminicídio, o sujeito passivo requer uma qualidade especial, qual seja, ser mulher, conforme expresso no próprio inciso VI, $\S 2$ do artigo 121 do Código Penal. Ademais, cabe ressaltar que não só as esposas, companheiras, namoradas ou amantes estão sujeitas à vitimização de tal agir delituoso, mas qualquer outra mulher que mantenha o vínculo de relação doméstica, familiar, afetividade ou, fora deste âmbito, que seja morta por discriminação, menosprezo à sua condição de mulher (BRASIL, 2016d).

Nesse viés, oportuno que questiona-se a possibilidade de pessoas transexuais poderem figurar como agentes passivos do crime de feminicídio, havendo discussão doutrinária com dois posicionamentos acerca da questão. De um lado, uma corrente conservadora, defensora de que o transexual, geneticamente, não é mulher, o que descarta a hipótese de proteção especial; de outro, uma corrente moderna, que traz o entendimento de que, desde que a pessoa transexual 
transmute suas características sexuais, por cirurgia irreversível, deve ser encarada de acordo com sua nova realidade morfológica, admitindo sua proteção especial (CUNHA, 2016).

Após o estudo em relação ao bem jurídico tutelado e os sujeitos do crime de homicídio, também se faz pertinente breve apontamento de quando se inicia a vida extrauterina do indivíduo, vida essa protegida por intermédio do artigo 121 do Código Penal brasileiro, bem como quando se extingue.

Segundo a doutrina, a vida extrauterina começa a partir do início do parto e encerra-se com a morte, conforme leciona Greco (2009, p. 145):

[...] uma vez iniciado o trabalho de parto, com a dilatação do colo do útero ou com o rompimento da membrana amniótica, sendo o parto normal, ou a partir das incisões das camadas abdominais, no parto cesariana, até a morte do ser humano, que ocorre com a morte encefálica, nos termos do art. $3^{\circ}$, da Lei oํ 9.434/97, mesmo que haja vida intrauterina, poderá ocorrer o delito em estudo.

Nesse sentido, reafirma Hungria (1976, p. 38):

Somente pode ser sujeito passivo do homicídio o ser humano com vida,
mas o que é vida? Ou, mais precisamente: como ou quando começa a vida?
Dizia Casper: 'viver é respirar; não ter respirado é não ter vivido'. Formulado
assim irrestritamente, não é exato o conceito, ainda mesmo que
considerasse vida somente a que se apresenta de modo autônomo, per se
stante, já inteiramente destacado o feto do útero materno. A respiração é
uma prova, ou melhor, a infalível prova da vida; mas não é a imprescindível
condição desta, nem a sua única prova. O neonato apnéico ou asfíxico não
deixa de estar vivo pelo fato de não respirar. Mesmo sem a respiração, a
vida pode manifestar-se por outros sinais, como sejam o movimento
circulatório, as pulsações do coração, etc. É de notar-se, além disso, que a
própria destruição da vida biológica do feto, no início do parto (com o
rompimento do saco aniótico), já constitui homicídio, embora eventualmente
assuma o título de infanticídio (grifo do autor).

Diante das exposições realizadas pode-se entender que a vida humana extrauterina é protegida desde o momento do parto, seja ele normal ou cesariana, e que o crime de homicídio só pode se configurar a partir do começo do nascimento, quer dizer, com a vida extrauterina, de maneira que a destruição da vida intrauterina configura o delito de aborto. 
Observe-se que a destruição da vida intrauterina configura o delito de aborto (art. 124, CP). De outro lado, a morte dada ao feto durante o parto perfaz, em princípio, o delito de homicídio. Se o sujeito ativo for a mãe, sob influencia do estado puerperal, tem-se identificado o delito de infanticídio (art. 123, CP). Infere-se daí que o delito de homicídio tem como limite mínimo o começo do nascimento, marcado pelo início das contrações expulsivas. Nas hipóteses em que o nascimento não se produz espontaneamente, pelas contrações uterinas, como ocorre em se tratando de cesariana, por exemplo, o começo do nascimento é determinado pelo início da operação, ou seja, pela realização da incisão abdominal. De semelhante, nas hipóteses em que as contrações expulsivas forem induzidas por alguma técnica médica, o início do nascimento será sinalizado pela execução efetiva da referida técnica ou pela intervenção cirúrgica (cesárea) (PRADO, 2010, p. 46, grifo do autor).

Analisando o presente tópico se faz relevante ressaltar que o homicídio é um crime contra o bem jurídico vida e pode ser cometido por qualquer pessoa, contra qualquer pessoa, não sendo exigida nenhuma qualidade especial para se figurar no polo ativo ou passivo, exceto quando se tratar do crime de feminicídio, hipótese em que o sujeito passivo deve, necessariamente, ser mulher.

No próximo tópico será realizada uma abordagem acerca das qualificadoras do crime de homicídio, as quais podem ser de caráter objetivo ou subjetivo. A análise em questão se faz necessária para a discussão atinente a possibilidade de aplicação concomitante da qualificadora do feminicídio com determinadas qualificadoras de ordem subjetiva.

\subsection{Circunstâncias qualificadoras}

O Código Penal brasileiro prevê a ocorrência do crime de homicídio em várias modalidades, podendo ser doloso simples, doloso privilegiado, doloso qualificado, culposo e culposo majorado. No entanto, para propiciar a compreensão da temática desta pesquisa, se faz relevante discorrer, apenas, sobre a modalidade do homicídio qualificado e suas espécies, dentre as quais se vislumbra o feminicídio.

Destaca-se, de início, que o homicídio qualificado, previsto no artigo 121 , 2o, do Código Penal, é caracterizado por condutas que tornam o crime mais reprovável perante a sociedade. São circunstâncias que tornam o delito mais gravoso, razão pela qual há, nestes casos, um maior sancionamento. 
Considera-se qualificado o homicídio se impulsionado por certos motivos, se praticado com o recurso a determinados meios que denotem crueldade, insídia ou perigo comum ou de forma a dificultar ou tornar impossível a defesa da vítima; ou, por fim, se perpetrando com o escopo de atingir fins especialmente reprováveis (execução, ocultação, impunidade ou vantagem de outro crime) (PRADO, 2010, p. 51).

Desta forma, conforme alude Cunha (2016), pode-se dizer que as circunstâncias que qualificam o crime de homicídio podem ser de ordem subjetiva, quando ligadas aos motivos determinantes do crime, indiciários de depravação espiritual do agente, bem como, de ordem objetiva, quando ligadas ao modo maligno do agente, que acompanha o ato ou fato em sua execução.

As qualificadoras subjetivas do homicídio são caracterizadas pelos motivos determinantes que ensejaram na execução do delito, pela paga e promessa de recompensa, pelo motivo torpe, motivo fútil ou pela conexão com outro crime.

Previstos no parágrafo $2^{\circ}$, incisos I e II, do artigo 121 do Código Penal, o motivo torpe e o motivo fútil são qualificadores subjetivos.

Para que o crime de homicídio seja qualificado pelo motivo fútil sua motivação deve ser frívola, mesquinha, desproporcional e insignificante. O motivo é considerado fútil quando notadamente desproporcional ou inadequado do ponto de vista da sociedade em relação ao crime de que se trata (CAPEZ, 2015).

Motivo fútil é aquele pequeno demais para que na sua insignificância possa parecer capaz de explicar o crime que dele resulta. O que acontece é uma desconformidade revoltante entre a pequeneza da provocação e a grave reação criminosa que o sujeito lhe opõe (CUNHA, 2016, p.59).

Neste contexto, fútil é o motivo sem importância, leviano, a ninharia que leva o agente à prática desse grave crime, na inteira desproporção entre o motivo e a extrema reação homicida (MIRABETE, 2002).

É importante ressaltar que motivo fútil não deve ser confundido com ausência de motivo, pois, mesmo insignificante, há motivação. Também não se pode confundir com o motivo injusto, pois esse, embora não condizente com a ética e com o direito, pode não ser desproporcionado com o antecedente lógico do crime (PRADO, 2010).

A título de exemplificação, o motivo fútil pode ser vislumbrado quando o homicídio decorre de banais desacertos no trânsito; de pequenas discussões entre 
familiares por provocações ínfimas, dentre outros tantos motivos que extrapolam o limite entre a ação da vítima e a reação do agente homicida.

Assim como o motivo fútil, o motivo torpe também diz respeito à motivação do crime de homicídio, constituindo outra circunstância de ordem subjetiva. Porém, adequado se questionar no que consistiria o motivo torpe. Para que se possa explorar a resposta desta indagação se faz necessário observar alguns conceitos, dentre eles o de Mirabete (2002), segundo o qual torpe é o motivo abjeto, repugnante, ignóbil, desprezível, vil, profundamente imoral, que se encontra na escala mais baixa dos desvalores éticos e denota maior depravação espiritual do agente.

Na concepção de Bitencourt (2015, p. 85), "torpe é o motivo que atinge mais profundamente o sentimento ético-social da coletividade, é o motivo repugnante, abjeto, vil, indigno, que repugna a consciência média".

Nesse passo, pode-se reconhecer a torpeza, como o motivo que gera uma grande repulsa na coletividade, pois ofende profundamente o sentimento ético comum e denota a ausência de sensibilidade moral do agente, sendo, portanto, moralmente reprovável.

O Código Penal expressamente, no artigo 121, $\$ 2^{\underline{a} \text { a }}$, inciso II, consigna como motivo torpe o homicídio praticado mediante paga ou promessa de recompensa. Trata-se da modalidade específica da torpeza, tendo em vista que é a única expressamente mencionada, já que, nas demais, o legislador tratou de expressar de forma genérica, devendo o aplicador do Direito realizar a interpretação do caso concreto.

Esta forma específica de torpeza, ou seja, o homicídio praticado mediante paga ou promessa de recompensa, também denominado de homicídio mercenário, ocorre, quando o agente recebe um pagamento para praticá-lo, ou o comete apenas porque obteve a promessa de ser recompensado pelo ato (MIRABETE, 2002).

Há uma discussão doutrinária acerca da recompensa, quando se questiona se ela é limitada à retribuição de ordem econômica ou comportaria alguma outra contraprestação sem valor patrimonial.

Segundo Capez (2015. p. 73), "pode-se cogitar de qualquer outra espécie de paga ou promessa de recompensa que não seja em pecúnia, desde que tenha valor econômico". 
Compartilha do entendimento supracitado Nelson Hungria (1976), o qual refere que a paga feita ou recompensa prometida, tanto pode consistir em dinheiro, como em qualquer vantagem econômica; bem como Edgard Magalhães Noronha (1999, p. 25), o qual alude que "tanto a paga como a promessa podem não ter por objeto o dinheiro, mas outra vantagem econômica".

Em contraponto ao entendimento dos autores mencionados, Mirabete (2002) e Greco (2009) entendem que a recompensa não se limita apenas à vantagem econômica, isto é, independe da natureza patrimonial, podendo constituir qualquer outra forma de vantagem.

Apesar das discussões existentes, o entendimento prevalente é de que a recompensa deve ter natureza econômica. De qualquer forma, tal discussão é inócua em razão da existência da interpretação analógica; eis que o legislador, após trazer o rol exemplificativo, emprega a expressão genérica, permitindo ao aplicador do direito encontrar outros casos que possam caracterizar o motivo torpe (CUNHA, 2016).

Nessa conjuntura, a qualificação do homicídio pela paga ou promessa de recompensa dispensa o recebimento da vantagem econômica, bastando que a motivação do agente decorra deste interesse econômico, conforme leciona Prado (2010, p. 53):

\footnotetext{
Para reconhecimento da qualificadora, exige-se que a paga ou promessa de recompensa sejam o motivo que desencadeou a resolução delitiva, ou seja, que a conduta seja realizada em razão desse motivo. Dado que o ânimo de lucro deve ser o motivo propulsor da resolução delitiva, residindo a maior reprovabilidade da conduta na mera representação do proveito, é dispensável para a caracterização da qualificadora, a obtenção da vantagem visada. Não é preciso que o agente receba efetivamente o pagamento ou que a promessa seja cumprida, sendo suficiente que a prática do delito seja impulsionada por tal motivação.
}

A paga ou promessa de recompensa é a qualificadora que recai sobre o agente que recebe, ou iria receber uma vantagem econômica para cometer o delito. Assim como as demais motivações torpes, representa uma conduta moralmente reprovável, pois o seu motivo central para o cometimento do crime é o lucro, ou seja, o agente pratica o homicídio pelo motivo exclusivo de auferir benefício econômico.

Outra hipótese de qualificadora subjetiva é a da conexão (inciso $\mathrm{V}$ do $§ 2^{\circ}$, do artigo 121 do Código Penal), em que o homicídio é praticado para assegurar a 
execução, ocultação, impunidade ou vantagem de outro crime, ainda que este não se consume (BRASIL, 2016d).

Nessa hipótese, o homicídio não é o objetivo central da ação mas, sim, a prática do crime conexo, tanto que se dá a morte tão somente com o intuito de propiciar a execução deste último ou sua ocultação, impunidade ou vantagem (HUNGRIA, 1976, p. 55).

\begin{abstract}
Essas circunstâncias, que configuram a rigor motivo torpe, originam casos de conexão teleológica ou consequencial. A conexão teleológica ocorre quando o homicídio é perpetrado como meio para executar outro crime (homicídio para poder provocar um incêndio). A conexão consequencial ocorre quando é praticado ou para ocultar a prática de outro delito (homicídio contra o perito que vai apurar a apropriação indébita do agente), ou para assegurar a impunidade dele (homicídio da testemunha que pode identificar o agente como autor de um roubo), ou para fugir da prisão em flagrante (RT 434/358), ou para garantir a vantagem do produto, preço ou proveito de crime (homicídio contra o co-autor de roubo ou furto para apossar-se da res furtiva) (MIRABETE, 2002, p. 74, grifo do autor).
\end{abstract}

Enfatiza-se que a conexão teleológica caracteriza-se quando o homicídio é cometido para assegurar a execução de um crime futuro, como por exemplo, matar o vigilante da agência bancária, no dia anterior à prática do crime de roubo, enquanto a conexão consequencial é aquela em que o delito é praticado com a finalidade de ocultar, assegurar a impunidade ou a vantagem de um crime já cometido (GRECO, 2009).

Jesus (2001) faz referência para, além da conexão teleológica e consequencial à conexão ocasional, a qual, segundo ele, ocorre quando o homicídio é cometido por ocasião da prática de outro delito como, por exemplo, quando o sujeito está furtando e resolve matar a vítima por vingança, situação em que o agente responderia por furto em concurso material com homicídio.

Importante destacar que, conforme os ensinamentos de Capez (2015) e Gonçalves (2016), caso as qualificadoras do inciso V do artigo 121 do Código Penal não estivessem sido expressamente previstas no texto legal, seria possível o reconhecimento da qualificadora genérica do motivo torpe, pois é evidente a conotação imoral na motivação de quem mata para viabilizar outro crime ou garantir impunidade.

Introduzido recentemente no Código Penal pela Lei 꾸 13.142, de 07 de julho de 2015, o homicídio contra autoridade ou agente descrito, nos artigos 142 e 144 da Constituição Federal, integrantes do sistema prisional e da Força Nacional de 
Segurança Pública, no exercício de sua função ou em decorrência dela, ou contra seu cônjuge, companheiro ou parente consanguíneo, previsto no inciso VII do $§ 2^{\circ}$ do artigo 121, também constitui uma qualificadora subjetiva do delito de homicídio (BRASIL, 2016e).

Conforme Cunha (2016, p. 67), a criação da referida previsão legal visa:

Tentar prevenir ou diminuir crimes contra pessoas que atuam na área de segurança pública, pessoas que atuam no front no combate à criminalidade. A mudança, conforme a Casa de Leis, é crucial para fortalecer o Estado Democrático de Direito e as instituições legalmente constituídas para combater o crime, em especial o organizado, o qual planeja criar pânico e o descontrole social, quanto um ator do combate à criminalidade é vítima de homicídio.

É pressuposto para a incidência da qualificadora em questão que a vítima se encontre no exercício de sua função ou, em estando de folga, o crime seja praticado em razão dela. No que tange aos crimes cometidos contra cônjuges, companheiros ou parentes do servidor público, é necessário comprovar que a agressão ocorreu em razão desta condição, tal como expressamente exige o dispositivo em estudo (GONÇALVES, 2016).

Ressalta-se que, em relação ao parentesco, a lei abrange apenas os parentes até o terceiro grau na linha reta (pai ou filho, avô ou neto, bisavô ou bisneto) e colateral (irmão, tio ou sobrinho), não se estendendo a qualificadora ao parentesco por afinidade (BRASIL, 2016e).

O homicídio praticado contra a mulher, por razões da condição de sexo feminino, denominado feminicídio, também foi recentemente incluído no rol dos homicídios qualificados. Previsto no artigo 121, $\S 2^{\circ}$, inciso VI do Código Penal, considera-se que há razões de condição de sexo feminino, de acordo com o $§ 2^{\circ}-A$, do dispositivo legal em comento, quando o crime envolve violência doméstica e familiar e menosprezo ou discriminação à condição de mulher (BRASIL, 2016d).

Tendo em vista que o tema central do presente trabalho é o feminicídio e que uma das questões principais diz respeito ao estudo da natureza da referida qualificadora, por ora, apenas se faz menção a tal modificação legislativa, deixando seu aprofundamento para momento posterior.

Ainda, cumpre mencionar que não é possível o cabimento de circunstância qualificadora de natureza subjetiva em concomitância com circunstância privilegiadora de natureza subjetiva. Salienta-se que as três hipóteses de privilégio 
estão previstas no artigo 121, $\S 1^{\circ}$, do Código Penal e são de caráter subjetivo porque se referem, assim como as qualificadoras de natureza subjetiva, à motivação do agente; por esta razão é fácil compreender que a motivação de um homicídio não pode ser ao mesmo tempo autorizadora de uma privilegiadora e de uma qualificadora (GONÇALVES, 2012).

No que pertine às qualificadoras do homicídio de ordem objetiva, são elas determinadas pelos meios e formas de execução do delito.

Previstas no artigo 121, $\S 2^{\circ}$, inciso III, do Código Penal, as qualificadoras determinadas pelos meios de execução se referem ao homicídio praticado com o emprego de veneno, fogo, explosivo, asfixia, tortura ou outro meio insidioso ou cruel, ou que possa resultar perigo comum. Tratam-se de qualificadoras objetivas, pois se referem aos modos de execução do crime, os quais denotam a perversidade do agente. Conforme dispõe Greco (2009, p. 167), "tudo aquilo que for considerado meio insidioso, cruel ou de que possa resultar perigo comum qualificará o homicídio [...]", eis as principais características das qualificadoras de natureza objetiva do homicídio.

Novamente o texto legal faz casuística exemplificativa e termina com uma fórmula genérica, de maneira que, em não se tratando dos casos expressamente específicos, o aplicador do direito deverá se utilizar da interpretação analógica para determinar se o delito se enquadra nesta qualificadora. Os meios que qualificam o crime devem ter a mesma natureza do conteúdo específico (CAPEZ, 2015).

O primeiro meio insidioso a que a lei se refere é o homicídio praticado mediante o emprego de veneno. Este meio é considerado letal insidioso por excelência, pois seu êxito está condicionado à sua própria dissimulação, tendo em vista que, para que se configure a presente qualificadora, a vítima não pode ter conhecimento de que está sendo envenenada, isto é, o crime só é qualificado quando for executado de maneira dissimulada, com estratagema, como cilada (BITENCOURT, 2015).

De acordo com a doutrina, considera-se veneno qualquer substância mineral, animal, ou vegetal - que, inoculada, ingerida ou introduzida no organismo, provoque lesão ou perigo de lesão à saúde ou à vida (PRADO, 2010).

Mirabete (2002) leciona que o veneno pode ser sólido, líquido, gasoso e administrado por diversos modos, tais como, via bucal, nasal, retal, vaginal, hipodérmica, intravenosa, dentre outros. 
Destaca-se que uma substância inócua pode tornar-se venéfica pelas condições especiais da vítima, vindo a causar-Ihe a morte; a título de exemplo, o açúcar é uma substância inofensiva para a grande maioria de pessoas, entretanto, pode ser letal ao diabético (HUNGRIA, 1976).

Outra observação importante diz respeito à circunstância de a qualificadora só se configurar quando a vítima não possuir a ciência de que está sendo envenenada ou restar iludida desta prática. Desta forma, o envenenamento violento ou sem insídia pode configurar a qualificadora genérica do emprego de meio cruel, mas não a de emprego de veneno (GRECO, 2009).

A utilização de fogo e de explosivo também qualifica o homicídio, uma vez que se trata de meio extremamente cruel à sua execução, e podem, dependendo de suas circunstâncias, resultar em perigo comum (CABETTE, 2012).

O fogo não é só um meio cruel (p. ex., o caso de play-boys que o atearam em um pobre homem que se achava dormindo num banco de jardim público) como também de perigo comum: incendiar uma casa para matar seus moradores, expondo vizinhas ao risco de incêndio (NORONHA, 1999, p. 26).

Por explosivo entende-se qualquer objeto ou artefato, capaz de provocar explosão ou qualquer corpo, capaz de se transformar rapidamente em uma explosão (BITENCOURT, 2015).

\begin{abstract}
$\mathrm{Na}$ sua decomposição brusca, passando do estado sólido ou líquido ao estado gasoso, o explosivo opera a violenta deslocação e destruição de matérias circunjacentes. Não há que distinguir entre substâncias e aparelhos ou engenhos explosivos. Entre os explosivos mais conhecidos, podem ser citados os derivados da nitroglicerina (dinamite), da nitrobenzina (belite), do nitrocresol (cresolite), da nitronaftalina (schneiderite, chedite), do nitrotuleno (trotil ou tolite), do trinitofenol ou ácido pírico (melinite, lidite), o algodão-pólvora (explosivo mediante choque), os fulminatos, os explosivos com base de ar líquido, etc (HUNGRIA, 1976, p. 166).
\end{abstract}

O explosivo, como citado, é meio cruel e também pode representar perigo comum, tendo em vista que, quando utilizado pelo agente, enseja perigo a um número indeterminado de pessoas.

Constitui meio cruel, também, o homicídio causado por asfixia, a qual pode ser alcançada por esganadura (constrição no pescoço da vítima com as mãos), enforcamento (constrição pelo próprio peso da vítima), estrangulamento (constrição muscular com fios, arames, cordas), soterramento (submersão em meio sólido), 
afogamento (submersão em meio líquido) ou confinamento (colocação em local em que não penetre o ar) (MIRABETE, 2002).

Consoante Prado (2010), trata-se de forma inequivocamente cruel de provocar a morte, consistente no obstáculo da função respiratória, morte essa que se perfectibiliza pela falta de oxigênio no sangue.

A tortura igualmente se encontra no rol dos meios considerados cruéis, qualificando o homicídio. Nas palavras de Capez (2015, p. 79), a tortura:

É o suplício ou tormento, que faz a vítima sofrer desnecessariamente antes da morte. É o meio cruel por excelência. O agente, na execução do delito, utiliza-se de requintes de crueldade como forma de exacerbar o sofrimento da vítima, de fazê-la sentir mais intensa e demoradamente as dores.

A tortura pode ser tanto física como moral. A física visa causar sofrimento pelo corpo, de forma que o agente pode mutilar a vítima (decepar dedos, orelhas), queimá-la, dar choques elétricos, dentre tantas outras formas capazes de machucar, ferir e causar profundo sofrimento. O objetivo da tortura física é matar a vítima aos poucos, fazendo com que ela sinta mais intensa e demoradamente as dores. Já a tortura moral consiste em causar terror ou angústia na vítima, como por exemplo, matar uma pessoa cardíaca torturando-a moralmente (NORONHA, 1999).

Cabe ressaltar que, para a incidência desta qualificadora, o agente deve empregar a tortura com o objetivo de querer ou assumir o risco de produzir 0 resultado morte, diferentemente do que se verifica no crime de tortura qualificada, prevista no artigo $1^{\circ}$ da Lei $n^{-9} 9.455 / 97$. No referido caso, a tortura qualificada pelo resultado morte é preterdolosa, ou seja, o resultado agravador é gerado por culpa do agente, pois ele atua com dolo em relação à tortura e com culpa em relação ao resultado agravador (morte) (CAPEZ, 2015).

\footnotetext{
Se, entretanto, durante a tortura o agente resolve matar a vítima, p. ex., a tiros de revólver, há dois crimes em concurso material: tortura (art. 1ํ da Lei no 9.455/97) e homicídio, que pode ser qualificado por motivo torpe, recurso que impediu a defesa da vítima etc. (JESUS, 2001, p. 69).
}

A lei também faz referência, de maneira genérica, a outro meio insidioso ou cruel, ou que possa resultar perigo comum. Em relação a esta disposição, Mirabete (2002) ressalta que o que qualifica o homicídio não é propriamente o meio escolhido ou usado para a prática do crime e, sim, o modo insidioso com que o agente 0 
executa, empregando, para isso, recurso que dificulte ou torne impossível a defesa, como por exemplo, uma armadilha, a sabotagem de um motor de automóvel, o fazer experimentar uma arma de fogo cuja explosão, por um desconserto do maquinismo, volte contra quem usa.

Em síntese, meio insidioso é o meio dissimulado na sua eficiência maléfica, utilizado pelo agente sem que a vítima dele tome conhecimento.

Cruel, em seu turno, é aquele que causa um sofrimento excessivo, desnecessário à vítima enquanto viva, obviamente, pois a crueldade praticada após a sua morte não qualifica o delito (GRECO, 2011).

\begin{abstract}
Meio cruel é todo aquele que produz um padecimento físico inútil ou mais grave do que o necessário e suficiente para a consumação do homicídio. É o meio barato, martirizante, denotando, da parte do agente, a ausência de elementar sentimento e piedade [...]. São meios cruéis, por exemplo, as sevícias reiteradas, o impedimento de sono, a privação do alimento ou água, o esfolamento, a ministração de chumbo derretido, dentre outros tantos (HUNGRIA, 1976, p. 167).
\end{abstract}

Já o meio de que possa resultar perigo comum, também previsto no artigo 121, § 2을 inciso III, do Código Penal, é aquele que, além de atingir a vítima almejada, pode criar uma situação de perigo extensivo a um indeterminado número de pessoas. Pode-se citar dentre os crimes que causam perigo comum, como já visto, o homicídio praticado com o emprego de fogo e explosivo.

Nada impede que haja concurso formal do homicídio com um crime de
perigo comum, quando o meio escolhido pelo sujeito ativo, além de atingir a
vítima visada, criar também a situação concreta de perigo para um número
indeterminado de pessoas, como por exemplo, incêndio (art. 250), explosão
(art. 251), inundação (Art. 254), desabamento (art. 256) etc. (BITENCOURT,
2015, p. 90).

Encerradas as circunstâncias qualificadoras pelos meios de execução do homicídio, passa-se a discorrer acerca das circunstâncias que qualificam o delito pela sua forma de execução.

As qualificadoras do crime de homicídio pela forma de execução também são de natureza objetiva e estão descritas no inciso IV, do $\S 2$ o do artigo 121 do Código Penal, na qual o legislador traz uma hipótese de interpretação analógica, quando, logo após o rol específico de circunstâncias (traição, emboscada e 
dissimulação), há a designação genérica (outro recurso que dificulte ou torne impossível a defesa do ofendido) (BRASIL, 2016d).

Um dos modos de execução específico que qualifica o crime de homicídio é a traição. Nas palavras de Nucci (2014, p. 930), trair significa:

[...] enganar, ser infiel, de modo que, no contexto do homicídio, é a ação do agente que colhe a vítima por trás, desprevenida, sem ter esta qualquer visualização do ataque. $O$ ataque súbito, pela frente, pode constituir surpresa, mas não traição.

Por sua vez, Hungria (1976, p. 168.) define o homicídio por traição como aquele "cometido mediante ataque súbito e sorrateiro, atingida a vítima, descuidada ou confiante, antes de perceber o gesto criminoso".

Pode-se dizer que, para o reconhecimento desta qualificadora, é necessária a demonstração de que havia uma prévia relação de confiança entre as partes e que o agente tenha se valido desta situação para, sem que a vítima esperasse, matá-la (GONÇALVES, 2012).

Outra forma de execução expressa no Código Penal é a emboscada, que corresponde ao ocultamento do agente, o qual clandestinamente aguarda a vítima com o propósito de surpreendê-la e agredi-la (PRADO, 2010). Nas palavras de Cabette (2012, p. 27), "emboscada configura-se com a tocaia, onde o agente permanece escondido à espera da vítima".

Encerra-se o rol exemplificativo dos modos de execução que qualificam o crime de homicídio com a dissimulação que, na lição de Mirabete (2002), nada mais é do que o emprego de recurso que distrai a atenção da vítima do ataque do agente.

Greco (2014) expõe que dissimular significa ocultar a intenção homicida, fazendo-se passar por amigo, conselheiro, enfim, dando falsas amostras de amizade a fim de facilitar o cometimento do delito.

No mesmo sentido, Hungria (1976, p. 169) refere que:

Dissimulação é a ocultação da intenção hostil, para acometer a vítima de surpresa. O criminoso age com falsas mostras de amizade, ou de tal modo que a vítima, iludida, não tem motivo de desconfiar do ataque e é apanhada desatenta e indefesa.

Completando o inciso IV do $\S 2^{\circ}$ do artigo 121 do Código Penal, que prevê as circunstâncias que qualificam o crime de homicídio pela forma que este é 
executado, encontra-se a previsão genérica "outro recurso que dificulte ou torne impossível a defesa do ofendido", que, conforme leciona Greco (2014, p. 930):

\begin{abstract}
Ao generalizar, fornecendo de antemão exemplos, deixa a lei penal bem claro que o objetivo desta qualificadora é punir mais severamente o agente que, covardemente, mata o ofendido. Traindo-o, emboscando-o ou ocultando suas verdadeiras intenções, está prejudicando ou impedindo qualquer reação de sua parte, que se torna presa fácil. Entretanto, há a possibilidade de surgirem outros aspectos dessa modalidade pusilânime de agir, o que permite o encaixe na figura genérica.
\end{abstract}

Cabette (2012) cita como exemplos de formas de execução que se enquadrariam na forma genérica, aqueles cometidos com armadilhas ocultas, ataques surpresas, dentre outros que comprometam a possibilidade de defesa da vítima.

Ademais, se faz importante referir que a fórmula genérica do dispositivo só compreende hipóteses assemelhadas aos casos anteriormente arrolados, ou seja, é necessário que o outro recurso tenha a mesma natureza das qualificadoras elencadas no inciso IV do $\S 2^{\circ}$, do artigo 121 do Código Penal, quais sejam, traição, emboscada ou dissimulação.

O homicídio qualificado, por meio da forma de execução, revela a covardia do agente que se utiliza da boa-fé ou desprevenção da vítima para praticar o crime, isto é, o agente age com insídia, aproveitando-se, muitas vezes, da confiança da vítima, a qual, inesperadamente é executada sem a menor chance de oferecer qualquer forma de defesa.

Realizada a abordagem acerca das qualificadoras subjetivas e objetivas do crime de homicídio, pertinente a análise da competência para julgamentos de tal tipificação penal.

\title{
3.3 Competência para julgamento
}

O Tribunal do Júri é um órgão da justiça comum, colegiado e heterogêneo, composto por um juiz de direito e por juízes de fato, esses escolhidos dentre as pessoas do povo, e tem por finalidade julgar os crimes dolosos contra a vida (TASSE; GOMES, 2012).

No que tange ao procedimento deste órgão, compreende duas fases. Neste sentido, assevera Bonfim (2015, p. 713): 
O procedimento do Tribunal do Júri é bifásico ou escalonado, compreende uma fase preliminar, preparatória, seguida de uma fase definitiva. A fase preparatória volta-se ao julgamento da denúncia, resultando em um juízo de admissibilidade da acusação. A fase definitiva, em contrapartida, tem por fim o julgamento da causa, transferindo aos jurados o exame da procedência, ou improcedência, da pretensão acusatória (grifo do autor).

Nucci (2015), no entanto, entende que o procedimento do Júri é trifásico, pois, em sua concepção, além da preparatória, denominada judicium accusationis, e da que constitui o momento do julgamento do processo, denominada judicium causae, também haveria a da preparação do plenário, prevista após a edição da Lei no 11.689/08, na Seção III, do Capítulo II, como específica, o que confirmaria a existência de três estágios para atingir o julgamento de mérito.

$\mathrm{Na}$ concepção de Tasse e Gomes (2012), apesar de formalmente o procedimento do Júri possuir três fases, considera-se que ele conta com duas, quais sejam a formação de culpa e o julgamento do caso, sendo que a preparação é apenas uma etapa que antecede a segunda fase.

A primeira fase do procedimento bifásico do Júri "inicia-se com o recebimento da peça inicial acusatória, terminando no momento em que preclui a decisão de pronúncia" (BONFIM, 2015, p. 721).

\footnotetext{
A primeira fase (judicium accusations) ocorre perante $o$ juiz sumariamente (juiz togado que preside a instrução preliminar) que decidirá se o fato criminoso em análise tem ou não viabilidade (plausibilidade), se é ou não da competênciado Tribunal do Júri, se deve ou não ser levado ao julgamento dos jurados (TASSE; GOMES, 2012, p. 51).
}

Nesse tocante, ressalta-se que é na primeira fase do procedimento que o juiz irá apreciar todos os elementos necessários para construir sua convicção sobre o fato delituoso, tendo em vista que, quando da decisão de pronúncia, esta deverá estar atrelada ao disposto no artigo 413 do Código de Processo Penal, ocorrendo apenas quando o juiz, fundamentadamente, admitir a existência de provas sobre a materialidade do fato e indícios suficientes de autoria ou participação (BRASIL, 2016f).

Havendo a decisão de pronúncia do acusado, passa-se à segunda fase do procedimento do Tribunal do Júri, qual seja a judicium causae. Esta se inicia com a preclusão da decisão da pronúncia, quando os autos serão encaminhados ao juiz presidente do Tribunal do Júri para a preparação do processo e julgamento em 
plenário, conforme artigo 421 do Código de Processo Penal, encerrando-se com a conclusão final do processo (JESUS, 2010).

Em relação aos princípios constitucionais atribuídos ao instituto do Júri, pode-se dizer que, após longa evolução histórica diante dos textos constitucionais existentes no Brasil, a atual Constituição Federal de 1988, no capítulo dos direitos e

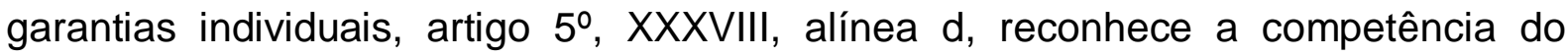
Tribunal do Júri para julgar os crimes dolosos contra a vida, assegurando os princípios da plenitude de defesa, sigilo das votações e soberania dos veredictos, os quais já haviam sido previstos pela Carta de 1946, porém, na Constituição de 1967, período em que perdurava a ditadura militar, haviam sido suprimidos do texto legal (NUCCI, 2015).

Tendo em vista que o artigo 60, $\S 4^{\circ}$, inciso IV, da Constituição Federal dispõe que não pode ser objeto de deliberação qualquer proposta de Emenda Constitucional tendente a abolir direitos e garantias individuais, o Tribunal do Júri está resguardado constitucionalmente como cláusula pétrea e não pode ser extinto. (BRASIL, 2016c).

Dentre os direitos e garantias individuais e, acima de tudo, fundamentais asseguradas constitucionalmente ao Tribunal do Júri, encontra-se a plenitude de defesa. Primeiramente se faz necessário destacar que este princípio difere do princípio da ampla defesa, pois, apesar de alguns doutrinadores entenderem que ambos os termos, ampla e plenitude, possuem o mesmo significado, a equiparação não soa corretamente. Consoante os ensinamentos de Nucci (2015, p. 27) "amplo é algo vasto, largo, copioso, enquanto pleno equivale a completo, absoluto. Somente por esse lado já se pode visualizar a intencional diferenciação dos termos".

Quando se recorre à plenitude da defesa, recorre-se a uma argumentação extrajurídica, apela-se para as questões de ordem moral, social, filosófica, recorre-se à retórica, ao convencimento pela emoção, sim, às razões de ordem emocional. É o Júri. Tão democrático. (ALBUQUERQUE, 2010, p. 81).

Ressalta-se que, tanto plenitude de defesa como ampla defesa são princípios constitucionais e que a principal diferença entre eles é que, no Tribunal do Júri, há o alargamento do direito de defesa, que possibilita ir além do que está escrito na lei, de maneira que o princípio da plenitude de defesa se sobressai perante a ampla defesa. 
O princípio do sigilo das votações, como já enunciado, também corresponde a uma das garantias constitucionais provenientes ao instituto do Júri. Compreendese por este princípio a incomunicabilidade entre os jurados sobre o fato do julgamento, ou seja, no momento do voto, não é permitido aos jurados qualquer tipo de comunicação ou de diálogo sobre a decisão a ser tomada. Não é possível identificar o voto dos jurados, uma vez que votam em sigilo e não possuem qualquer possibilidade de comunicação (TASSE; GOMES, 2012).

Da mesma forma, é assegurado ao Tribunal do Júri o princípio da soberania dos vereditos, o qual importa na compreensão de que nenhuma decisão fundamentada em veredito dos jurados pode ser substituída por outra sentença sem esta base, ou seja, como o nome do próprio princípio sugere, o Júri é soberano em suas decisões.

Ocorre que a referida garantia não é absoluta, pois há a possibilidade de, existindo error in judiciando, o julgamento ser anulado e outro ser determinado em seu lugar, isso sem afrontar a soberania dos vereditos (ALBUQUERQUE, 2010).

Consoante os ensinamentos de Nucci (2015), soberano significa poder supremo, acima do qual não há outro. Realizando a análise deste significado, no âmbito do princípio constitucional da soberania dos vereditos, pode-se dizer que o veredito popular é a última palavra, não podendo ser contestada, quanto ao mérito, por qualquer Tribunal togado, uma vez que os jurados decidem de acordo com suas consciências e não segundo as leis.

Por fim, no que tange aos princípios constitucionais assegurados ao instituto do Júri, a alínea d, do dispositivo em comento, expressa a competência do Tribunal do Júri para o julgamento dos crimes dolosos contra a vida, expressos no artigo 74 , $\S 1^{\circ}$, do Código de Processo Penal, sendo eles, o homicídio (artigo 121 e seguintes), o induzimento, a instigação ou auxílio ao suicídio (artigo 121 e seguintes), o infanticídio (artigo 123) e o aborto (artigo 124 e seguintes). Ressalta-se que estes delitos podem ser, na forma consumada ou tentada, com exceção do induzimento, da instigação ou auxílio ao suicídio, que não permitem a forma tentada (BRASIL, 2016c). 
O dispositivo trata da competência mínima do Júri, não podendo a legislação infraconstitucional retirar do tribunal popular a competência para o julgamento dos crimes dolosos contra a vida. Nada impede, entretanto, que o legislador ordinário alargue essa competência, incluindo outras figuras criminais. Não se trata de competência exclusiva, cabendo ao Tribunal do Júri julgar outros crimes, desde que haja conexão ou continência com algum crime doloso contra a vida (BONFIM, 2015, p. 709).

Destarte, o Tribunal Popular também possui competência para julgar os crimes que tenham conexão com os crimes dolosos contra a vida. Destaca-se que, somente neste caso, o Tribunal do Júri julgará crimes que ofendem outros bens jurídicos, que não a vida diretamente (TASSE; GOMES, 2012).

Enfatiza-se que o feminicídio constitui uma das modalidades qualificadas do crime de homicídio e, por consequência lógica, o julgamento deste delito, na forma tentada ou consumada, será também de competência do Tribunal do Júri, razão pela qual discorre-se a respeito deste instituto na presente pesquisa.

Ressalta-se que, de acordo com o exposto no artigo 436, caput, do Código de Processo Penal, o jurado do Tribunal do Júri pode ser qualquer cidadão com mais de 18 anos e de notória idoneidade, que goze de seus direitos políticos, não sendo levado em consideração para este dever, qualquer condição referente à cor, etnia, raça, credo, sexo, profissão, classe social ou econômica, origem ou grau de instrução, ou seja, nenhuma condição isenta o jurado de atuar, exceto indivíduos analfabetos, surdo-mudo ou com grave deficiência físicas (JESUS, 2010).

Diante do contexto abordado, pode-se dizer que o Tribunal do Júri é uma garantia fundamental que consiste na participação do povo nos julgamentos dos crimes dolosos contra a vida, sendo que sua previsão legal constitui uma cláusula pétrea, razão pela qual não é passível de ser abolida. Ademais, o Tribunal do Júri tem por propósito que os agentes cometedores de crimes dolosos contra a vida sejam julgados por seus pares.

Em relação ao julgamento do feminicídio pelo Tribunal do Júri, perfazendo uma análise do que já foi discorrido no capítulo anterior, constata-se que, antes da evolução dos direitos das mulheres, mais precisamente, antes do advento da Lei no 11.340/06 e da Lei oㅜ 13.104/15, o delito atualmente tipificado como feminicídio já era de competência do Tribunal do Júri, porém, devido ao patriarcado persistente na sociedade, custaram a ser condenados como de fato deveriam. Nos dias atuais, pode-se afirmar que, além da concepção da sociedade em relação ao tratamento da mulher estar em constante evolução, o que acaba por refletir diretamente nas 
decisões do Tribunal do Júri, uma vez que este é composto por pessoas da sociedade, a nova tipificação feminicídio veio elucidar o vislumbre dos jurados diante do caso concreto, tendo em vista que agora há um tipo penal específico para os assassinatos praticadas contra as mulheres por razão de sexo feminino.

Após a abordagem realizada neste capítulo, que se confirmou de suma importância para a problemática proposta, se passará ao estudo do feminicídio propriamente dito, a fim de se elucidar a discussão acerca da ocorrência ou não do bis in idem diante da aplicação da qualificadora do feminicídio e de outras qualificadoras do homicídio. 


\section{FEMINICÍDIO NO CÓDIGO PENAL BRASILEIRO}

O presente tópico versa a respeito da qualificadora do homicídio praticado contra a mulher em virtude do sexo feminino, o feminicídio, realizando a verificação quanto a sua natureza e algumas de suas peculiaridades para que se possa tecer uma análise acerca da (in) ocorrência da violação do ne bis in idem quando tal situação é cumulada com outras circunstâncias qualificadoras do homicídio.

\subsection{A punição do homicídio perpetrado contra a mulher antes da qualificadora do feminicídio e os motivos de sua tipificação}

Antes da promulgação da Lei oำ13.104/2015, que incluiu o feminicídio no rol dos homicídios qualificados, bem como dos crimes considerados hediondos, não havia qualquer punição específica para aquele, ou aquela, que causasse a morte de mulheres em razão do gênero, sendo esta conduta delituosa abarcada, de forma genérica, pelo artigo 121 do Código Penal.

Dependendo do caso concreto, o homicídio praticado contra a mulher poderia ser qualificado pelo motivo torpe previsto no artigo $121, \S 2$, inciso I, do Código Penal, o qual, como visto, representa o motivo vil, repugnante, abjeto, moralmente reprovável. Nota-se que, antes da criação do feminicídio, a prática de homicídios em razão do gênero era propagada como crime passional, quando não privilegiado (SOUZA, 2015).

É preciso colocar os avanços legislativos em prática, para que o feminicídio não seja minimizado no sistema de justiça e na imprensa por meio de classificações como 'crime passional' ou 'homicídio privilegiado', quando o autor age sob violenta emoção, teoricamente motivada por uma ação da vítima (INSTITUTO PATRÍCIA GALVÃO, 2015, grifo do autor).

O propósito da atual qualificadora é extirpar essa ideia de "crime por amor", pois rotular o homicídio cometido em face da mulher em razão de gênero como crime passional é camuflar a cultura patriarcal existente na sociedade, é amenizar as reais motivações do agressor fazendo com que o delito pareça menos grave do que realmente é (SOUZA, 2015, grifo do autor).

Diante disso, pode-se afirmar que a criação do feminicídio foi de grande relevância, visto que, mesmo essa figura sendo nada mais do que o próprio crime de 
homicídio, porém cometido em razão da condição do sexo feminino, sua existência penal é singular, com nome específico, estabelecendo uma voz própria para designar a matança de mulheres e constituindo um importante passo rumo ao conhecimento desta forma de violência (ZANELLA et al., 2015).

Neste diapasão, cita-se a justificativa do Projeto de Lei nº 292/2013, apresentada pelo Senado Federal para explicar a tipificação de feminicídio:

\begin{abstract}
A importância de tipificar o feminicídio é reconhecer, na forma da lei, que mulheres estão sendo mortas pela razão de serem mulheres, expondo a fratura da desigualdade de gênero que persiste em nossa sociedade, e é social, por combater a impunidade, evitando que feminicidas sejam beneficiados por intepretações jurídicas anacrônicas e moralmente inaceitáveis, como o de terem cometido 'crime passional'. Envia, outrossim, a mensagem positiva à sociedade de que o direito à vida é universal e de que não haverá impunidade. Protege, ainda, a dignidade da vítima, ao obstar de antemão estratégias de se desqualificarem, midiaticamente, a condição de mulheres brutalmente assassinadas, atribuindo a elas a responsabilidade pelo crime de que foram vítimas.
\end{abstract}

Em suma, pode-se dizer que a tipificação do feminicídio foi uma resposta à cultura de impunidade e benevolência em que os assassinos de mulheres se encontravam. Foi um instrumento legal criado pelo legislador para punir esta conduta criminosa que vinha, por muito tempo, sendo mascarada por meio de denominações que, como dito, diminuíam sua gravidade.

Oportuno mencionar que as leis penais mais gravosas só produzem efeitos em relação aos fatos ocorridos durante o período de sua vigência. Especificamente no âmbito do Direito Penal não é possível que ela retroaja para prejudicar os acusados, isso porque "em matéria de sucessão de leis no tempo que regulem a intervenção punitiva, a Constituição Federal, no inc. XL de seu art. 5ํㅗ garante a irretroatividade da lei penal, salvo se a retroatividade de qualquer forma trouxer benefício para o réu" (GALVÃO, 2013, p. 684).

Pode-se dizer, portanto, que a esse respeito o texto constitucional consagra dois princípios fundamentais, a proibição da retroatividade prejudicial (novatio legis in pejus) e a imposição da retroatividade benéfica (novatio legis in mellius) (GALVÃO, 2013). Nesse seguimento, estatui o parágrafo único do artigo $2^{\circ}$ do Código Penal: "A lei posterior que de qualquer modo favorecer o agente, aplica-se aos fatos anteriores, ainda que decididos por sentença condenatória transitada em julgado" (BRASIL, 2016d). 
Resumidamente, se o acusado praticou o homicídio contra a mulher por questão de gênero antes de 09 de março de 2015, data do advento da Lei 13.104, responderá pelo crime em sua forma simples ou com base em outras qualificadoras do homicídio que não o feminicídio.

Sucintamente, isso implica dizer que não é possível uma lei mais gravosa, promulgada após a ocorrência de um delito, retroagir e produzir efeitos ao acusado, razão pela qual o delito de homicídio praticado contra a mulher, por questões de gênero, antes do advento da nova legislação, não pode ser objeto de punição na forma do inciso VI do $\S 2^{\circ}$ do artigo 121 do Código Penal.

Feitas as considerações iniciais, necessárias em virtude da importância do tipo penal objeto da pesquisa e também para a conclusão adequada do estudo que se propôs realizar, será discorrido acerca da origem do termo feminicídio, seu conceito e a forma com que está previsto na legislação penal brasileira.

\subsection{Feminicídio: terminologia, conceito e previsão legal}

Para que se possam compreender quais crimes de homicídio contra a mulher se enquadram na qualificadora do feminicídio, necessário se faz realizar uma síntese acerca de sua terminologia, a fim de que se propicie o entendimento do conceito disposto pelo legislador, na tipificação deste delito, perante a legislação penal brasileira.

Primeiramente destaca-se que o termo feminicídio foi criado a partir da palavra femicídio, tendo sido esta referida pela primeira vez pela conhecida socióloga feminista Diana Russel, na celebração do simbólico Tribunal Internacional de crimes contra a mulher, ocorrida no ano de 1976 em Bruxelas. Posteriormente, no ano de 1992, o termo foi concretizado com a publicação do livro de Russel e Jill Radford, denominado Femicide: The Politcs of Woman Killing (COPELLO, 2012).

Segundo Souza (2015, p.19), "o termo foi utilizado por Russel para designar toda e qualquer forma de crime patriarcal e opressão sexual de mulheres". Já a palavra feminicídio, derivada do femicídio, foi criada no México pela feminista Marcela Lagarde, pois, para ela, femicídio seria o homicídio feminino, de modo que, de acordo com sua conceituação, feminicídio englobaria a violência exercida por homens contra mulheres pela condição de serem mulheres (SOUZA, 2015). 
Embora os dois termos sejam comumente empregados como sinônimos, hodiernamente tem sido realizada a diferenciação entre os conceitos. Enquanto femicídio é o homicídio de mulher, feminicídio é o homicídio de mulher por motivo de gênero, por ser a vítima do sexo feminino, envolvendo ódio ou menosprezo por sua condição (SILVA, [20--]b).

A Corte Americana de Direitos Humanos conceituou os assassinatos e desaparecimentos de meninas e mulheres que ocorreram em Ciudad Juarez no México, denominado "Caso Gonzáles y outra" (caso campo algodonero) como feminicídio, pois tais delitos representaram a expressão máxima da violência misógina. No caso em apreço, no qual o México foi condenado pela Corte Americana de Direitos Humanos, o Tribunal usou na sentença o termo feminicídio para denominar a morte de mulheres em razão do sexo (CORTE INTERAMERICANA DE DERECHOS HUMANOS, 2009, p. 41-42).

No mesmo sentido, o termo feminicídio foi utilizado, no ano de 2013 , pelo Congresso Nacional brasileiro, no relatório final da comissão parlamentar mista de inquérito, que tinha por finalidade investigar a situação de violência contra a mulher no Brasil e apurar denúncias de omissão, por parte do poder público, com relação à aplicação de instrumentos instituídos em lei para proteger as mulheres em situação de violência:

\begin{abstract}
O assassinato de mulheres pela condição de serem mulheres é chamado de 'feminicídio' - sendo também utilizados os termos 'femicídio' ou 'assassinato relacionado a gênero' - e se refere a um crime de ódio contra as mulheres, justificada socioculturalmente por uma história de dominação da mulher pelo gomem e estimulada pela impunidade e indiferença da sociedade e do Estado. O feminicídio é a instância última de controle da mulher pelo homem: o controle da vida e da morte. Ele se expressa como afirmação irrestrita de posse, igualando a mulher a um objeto, quando cometido por parceiro ou ex-parceiro; como subjugação da intimidade e da sexualidade da mulher, por meio da violência sexual associada ao assassinato; como destruição da identidade da mulher, por meio da violência sexual associada ao assassinato; como aviltamento da dignidade da mulher, submetendo-a a tortura ou a tratamento cruel ou degradante (SENADO FEDERAL, 2013, p. 1004).
\end{abstract}

Diante deste contexto, pode-se inferir que o legislador brasileiro se apoderou do termo feminicídio para designar o homicídio executado contra a mulher por razões da condição de sexo feminino, segundo as circunstâncias do artigo 121, §2º inciso VI, do Código Penal brasileiro. 
Ressalta-se que este novo tipo penal foi introduzido no rol dos homicídios qualificados (artigo 121, § $2^{\circ}$, inciso VI, do Código Penal) e, consequentemente, dos crimes hediondos (Lei $\mathrm{n}^{\circ}$ 8.072/90), o que se deu com o advento da Lei $\mathrm{n}^{\circ}$ 13.104/15, de forma que lhe é destinado tratamento mais severo, pois incide sobre o ele o apenamento mais rigoroso destinado aos homicídios qualificados, mais precisamente a reclusão de 12 a 30 anos, sem contar o regramento diferenciado previsto na Lei no 8.072/90, que impede o autor do crime de usufruir de alguns benefícios penais, como por exemplo, anistia, graça, indulto e fiança.

Consoante o Código Penal, em seu artigo 121, §2º inciso VI, matar alguém constitui homicídio qualificado quando o crime é cometido contra mulher por razões da condição de sexo feminino, condição essa que se configura, conforme o $§ 2^{\circ}$-A do respectivo dispositivo legal, quando o delito envolve violência doméstica e familiar ou menosprezo ou discriminação à condição de mulher. Eis a tipificação do crime de feminicídio (BRASIL, 2016d).

No que tange ao homicídio praticado contra mulher que envolva violência doméstica ou familiar (artigo 121, § 2ำ-A, inciso I, do Código Penal), necessário reportar-se à conjugação do conceito de violência doméstica e familiar contido no artigo $5^{\circ}$ da Lei 11.340/06, abordado no primeiro capítulo deste estudo. Sucintamente reitera-se que este conceito compreende qualquer ação ou omissão, baseada no gênero que Ihe cause morte, lesão, sofrimento físico, sexual ou psicológico e dano moral ou patrimonial, no âmbito da unidade doméstica, da família ou em qualquer relação íntima de afeto (BRASIL, 2016a).

Deste modo, enfatiza-se que nem todo homicídio de mulher será considerado feminicídio. Para que haja este delito, o homicídio precisa ter sido motivado em razão da condição de ser mulher. Aqui pode-se atestar a diferença entre os termos femicídio (homicídio de mulher) e feminicídio (homicídio contra mulher por ser mulher), nos moldes anteriormente aduzidos.

Silva ([20--]b s/p) destaca que, para ocorrer o feminicídio "o crime deverá se enquadrar nas hipóteses dos artigos $5^{\circ}$ e $7^{\circ}$ da Lei no 11.340/2006, ou quando houver menoscabo ou discriminação da mulher em razão de seu gênero". Nota-se, mais uma vez, a necessidade de compreensão das regras da Lei Maria da Penha para adequado entendimento do tipo penal em estudo.

No que concerne ao homicídio praticado contra a mulher por menosprezo ou discriminação à condição de mulher (artigo 121, §-A, inciso II, do Código Penal), 
relevante extrair o conceito trazido no artigo $1^{\circ}$ da Convenção sobre Eliminação de todas as Formas de Discriminação contra a Mulher (CEDAW) (1979, p. 20), em relação ao qual, como já visto, o Brasil é signatário:

\begin{abstract}
Para os fins da presente Convenção, a expressão 'discriminação contra a mulher' significará toda a distinção, exclusão ou restrição baseada no sexo e que tenha por objeto ou resultado prejudicar ou anular o reconhecimento, gozo ou exercício pela mulher independentemente de seu estado civil com base na igualdade do homem e da mulher, dos direitos humanos e liberdades fundamentais nos campos: político, econômico, social, cultural e civil ou em qualquer outro campo.
\end{abstract}

Sob a luz dos conceitos expostos, pode-se referir que o legislador buscou por meio da tipificação da qualificadora do feminicídio, em especial pelo descrito no artigo 121, $\S 2^{\circ}$, inciso II, do Código Penal, abarcar toda e qualquer forma de discriminação à mulher, bem como cumprir as diretrizes das convenções pelo Brasil ratificadas. É possível constatar, assim, que o feminicídio não se limitou a qualificar apenas os homicídios contra mulheres ocorridos em âmbito de violência doméstica e familiar (artigo 121, § 2 $2^{\mathfrak{a}}-\mathrm{A}$, inciso I, do Código Penal), mas também alcançar o delito cometido contra a mulher por questão de menosprezo à sua condição de ser mulher (artigo 121, § 2-A, inciso II, do Código Penal).

Especificamente em relação ao contido no artigo $121, \S 2^{\circ}-\mathrm{A}$, inciso II, do Código Penal, refere-se que pode ocorrer mesmo quando a vítima não possua nenhuma relação íntima de afeto com o sujeito ativo do crime. Gonçalves (2016, p. 164) leciona que "a vítima pode ser até mesmo uma mulher desconhecida do agente".

\begin{abstract}
Os estereótipos e os pré-conceitos de gênero estão na base das atitudes preconceituosas e discriminatórias contra mulheres e podem ser identificados em muitas situações: por exemplo, muitos homens acham que mulheres não devem trabalhar fora e são violentos quando elas procuram trabalho; na visão de que as adolescentes femininas são promíscuas, por isso podem ser estupradas; nos ditos populares mulher gosta de apanhar, em briga de marido e mulher ninguém mete a colher, matou por amor, dentre outros (CAMPOS, 2015, p. 112, grifo do autor).
\end{abstract}

Nesse particular, Delmanto et al. (2016, p. 683) dispõe que "menosprezo tem o sentido de depreciar, desprezar, desdenhar, ao passo de que discriminar alguém por ser mulher remete à ideia de preconceito, considerando-a inferior, não possuindo o mesmo valor, a mesma dignidade". 
Campos (2015) refere que o menosprezo à mulher pode ser constatado pela própria maneira com que o crime é executado, pois, quando o delito é motivado pela falta de apreço à condição feminina, este geralmente se direciona ao corpo da mulher, por exemplo, por meio de violência sexual, mutilação de seios, vagina, rosto e desfiguração.

Além da Lei n 13.104/15 inserir o feminicídio como uma das qualificadoras do crime de homicídio, ela também dispôs acerca das causas de aumento de pena. O $§ 7^{\circ}$, do artigo 121 do Código Penal dispõe que a pena, em caso de feminicídio, terá o aumento de um terço até a metade se o crime for praticado durante a gestação ou nos três meses posteriores ao parto, contra pessoa menor de 14 anos, maior de 60 anos ou com deficiência, ou na presença de descendente ou ascendente da vítima (BRASIL, 2016d).

Atribui-se o aumento de pena previsto para o feminicídio praticado contra a gestante ou nos três meses posteriores ao parto ao fato da gestação ser um período de intensa fragilidade feminina e à obrigação do Estado em preservar a vida e a saúde da gestante, bem como a do nascituro e do recém-nascido (OLIVEIRA; COSTA; SOUSA, 2015).

Já a majorante prevista no artigo 121, § 7º, inciso II, do Código Peal se dá quando o feminicídio é praticado contra pessoa menor de 14 ou maior que 60 e justifica-se pelo princípio da proteção integral assegurado pelo Estatuto da Criança e do Adolescente e pelo Estatuto do Idoso; eis que a vítima, nesses casos, apresenta menor chance de defesa, de maneira que a conduta do agente que comete o ilícito penal se reveste de maior covardia (SOUZA, 2015).

Quanto à causa de aumento de pena para o crime cometido contra pessoa com deficiência, também prevista no artigo 121, § 7ํㅜ, inciso II, do Código Penal, menciona-se que "como a lei é silente, deve-se entender que trata-se de qualquer espécie de deficiência, mas apta a diminuir a capacidade de resistência da vítima" (SILVA, [20--]b).

Por fim, o legislador tratou de prever como causa de aumento de pena o feminicídio cometido na presença de ascendente ou descendente da vítima. Neste caso, o aumento da penalidade justifica-se em decorrência do intenso sofrimento provocado no familiar de primeiro grau ao presenciar a ação criminosa. Destaca-se, quanto a isso, que a presença não precisa ser necessariamente física, podendo ocorrer por meio de áudio, vídeo, webcam, dentre outras formas (SOUZA, 2015). 
O fator determinante para que haja a incidência das majorantes previstas no $\S 7^{\circ}$, do artigo 121 do Código Penal é que o agente tenha ciência da circunstância que provoca o aumento da pena, tendo em vista que o desconhecimento desta implica no erro de tipo, impedindo a condenação pela forma legal mais gravosa (BIANCHINI; GOMES [20--]).

Diante da contextualização do feminicídio no ordenamento jurídico brasileiro, passa-se ao enfrentamento da problemática da compatibilidade ou não da citada qualificadora em relação a outras do homicídio, considerando a vedação ao bis in idem.

\subsection{A concomitância do feminicídio com qualificadoras subjetivas do homicídio sob o prisma da vedação ao bis in idem no direito penal brasileiro}

Constatou-se, em tempo anterior, que existem controvérsias em relação à natureza jurídica da qualificadora do feminicídio: se corresponde a uma qualificadora de ordem objetiva ou subjetiva. O debate em relação a tal questionamento é relevante ao deslinde do estudo monográfico, pois, a partir da resolução desta indagação, se poderá concluir a respeito da (in) ocorrência do bis in idem em relação à eventual concomitância da qualificadora do feminicídio com demais qualificadoras do homicídio previstas no Código Penal, em especial aquelas consideradas de ordem subjetiva.

De plano, cabível afirmar que "é possível que o homicídio tenha mais de uma qualificadora, tanto quanto se sabe que nem todas as qualificadoras são

compatíveis entre si. Jamais poderão, em um mesmo homicídio, coexistir duas qualificadoras de natureza subjetiva" (NABUCO FILHO, 2015, p. 204).

Por esta razão é que se busca identificar a natureza da qualificadora feminicídio, pois, sendo ela subjetiva, estaria impedida de coincidir com outras qualificadoras do homicídio desta mesma natureza, uma vez que haveria violação à proibição do bis in idem.

Para que se entenda no que consiste a violação do princípio ne bis in idem se faz necessário, primeiramente, aduzir que é por meio dele que há a proibição de alguém ser punido mais de uma vez pelo mesmo fato. Leciona Silva (2011, p. 17) que "deste princípio decorre que ninguém poderá ser processado (aspecto 
processual), condenado (aspecto material) ou executado (aspecto execucional) duplamente pelo mesmo fato" (grifo do autor).

Não é sabido exatamente quando este princípio surgiu, porém, para a maioria da doutrina, ele teria nascido no direito romano "como consequência lógica do instituto da coisa julgada, derivado do caráter preclusivo do processo, a partir da fase denominada litis contestatio, utilizada para solucionar eventual concorrência de ações" (SABOYA, 2006, p. 129, grifo do autor).

Embora o princípio do ne bis in idem não esteja previsto na Constituição Federal, admite-se a sua existência no sistema jurídico-penal brasileiro por se constituir como premissa à consecução de um Estado Democrático (ZANELLATO FILHO, 2015, p. 88).

\begin{abstract}
A proibição de múltipla persecução penal pelos mesmos fatos deriva dos princípios básicos do Estado democrático de direito, especialmente, do princípio da segurança jurídica, no sentido da impossibilidade de renovação ou julgamento de questão definitivamente resolvida, assim como em razão do reconhecimento da dignidade da pessoa humana e da tutela incessante da liberdade jurídica de todos os cidadãos, a qual limita a pretensão punitiva estatal (SABOYA, 2006, p. 143).
\end{abstract}

Inspirado nesses ideais, o legislador brasileiro ratificou acordos internacionais que preveem explicitamente a vedação ao bis in idem, sendo eles o Pacto Internacional sobre Direitos Civis e Políticos (artigo 14, $7^{\circ}$ ), Pacto de São José da Costa Rica (artigo $8^{\circ}, \S^{\circ}$ ) , e o Estatuto de Roma (artigo 20) (SILVA, 2011).

Portanto, tendo em vista que inclusive regramentos internacionais ratificados pelo Brasil reconhecem a impossibilidade de verificação de bis in idem em prejuízo de acusados no processo penal, imprescindível que se perquira se é ou não possível a verificação concomitante da qualificadora do feminicídio com as demais previstas no artigo 121 do Código Penal.

As qualificadoras do homicídio se dividem em dois grandes grupos: as de ordem subjetiva e as de ordem objetiva. Quando a doutrina se refere às qualificadoras subjetivas, ela aponta para as que dizem respeito aos motivos ou finalidades da consecução do delito, isto é, para àquelas previstas no artigo 121 , $2^{\circ}$, incisos I, II e V, do Código Penal. Já quando aponta para as objetivas, indica as que estão relacionadas ao modo ou meio utilizados para o acontecimento da morte de outrem, referindo àquelas previstas nos incisos III e IV do dispositivo legal em comento (OLIVEIRA, 2015). 
Sabe-se que não há incompatibilidade entre mais de uma qualificadora objetiva, uma vez que estas referem-se ao meio ou forma de consecução do delito, que pode, por exemplo, ser praticado com recurso que impossibilite a defesa da vítima e também por meio cruel. Tampouco existe esta incompatibilidade entre qualificadoras objetivas e subjetivas, pois o delito pode ser qualificado pela forma que foi executado, bem como pela motivação do agente. Deste modo, é importante que fique claro que não há dúvida da possibilidade de verificação da qualificadora do feminicídio de forma conjunta à outra qualificadora de ordem objetiva. A título de exemplo, pode-se dizer que não há qualquer impedimento na coincidência da qualificadora do feminicídio com a qualificadora do meio cruel.

Ao passo do exemplo mencionado, pertinente se faz trazer à baila o entendimento da 3a "âmara Criminal do Tribunal de Justiça do Estado do Rio Grande do Sul que decidiu, no acórdão do recurso em sentido estrito no 70068233998, julgado em 28 de setembro de 2016, pela manutenção da qualificadora do feminicídio em concomitância com a qualificadora objetiva do meio cruel. Na situação julgada, o denunciado teria assassinado sua esposa por meio de diversas e intensas facadas (TJRS, 2016).

Neste diapasão, tendo em vista que não há incompatibilidade entre a qualificadora do feminicídio e qualificadoras de natureza objetiva, ressalta-se que a solução buscada por meio da presente pesquisa restringe-se, especificamente, ao problema das qualificadoras de ordem subjetiva e sua verificação concomitante com a qualificadora do feminicídio.

A par do problema que se visa resolver, ressalta-se que, concernente à natureza jurídica da qualificadora do feminicídio, ainda não há um posicionamento definitivo quanto ao tema. Há quem diga que ela é objetiva como também quem admita que ela seja subjetiva. Além destes dois posicionamentos tradicionais, há também o de que esta qualificadora constitui uma nova natureza, diversa das existentes; ainda há quem defenda que a sua natureza é mista, dividida entre subjetiva e objetiva. Diante desta diversidade de posicionamentos, passa-se a verificação de cada um dentro de suas peculiaridades.

De início, refere-se o entendimento de que a qualificadora do feminicídio (artigo 121, § 20, inciso VI, do Código Penal) não teria natureza subjetiva e nem objetiva, mas sim, deveria constituir uma nova e peculiar natureza jurídica. 
Defensor dessa nova ideia, o Promotor de Justiça do Ministério Público do Distrito Federal e Territórios, Daniel Bernoulli Lucena de Olivera (2015) entende que o feminicídio não encontra amparo na classificação existente, pois não diz respeito nem ao motivo, tampouco ao modo de agir.

Em verdade, faz-se mister a criação de uma nova categoria, uma que abarque as qualificadoras que irão agravar a pena baseadas na pessoa da vítima, no ser, seja ele a mulher ou o policial, a qual poderíamos denominar de 'qualificadoras ontológicas' (OLIVEIRA, 2015, s/p).

Em relação à possibilidade de concomitância entre a qualificadora do feminicídio com outra de natureza subjetiva, Oliveira (2015) refere que, mesmo diante da necessidade de revisão de conceitos, não haveria impossibilidade destas subsistirem, conjuntamente:

[...] As qualificadoras ontológicas, recentemente ingressadas no tipo penal do homicídio, não geram qualquer embaraço junto a qualificadoras de cunho subjetivo, razão pela qual é absolutamente viável a coexistência dessas duas categorias quando do cometimento de um crime de homicídio.

Ainda, na definição sugerida, as qualificadoras seriam classificadas do seguinte modo: subjetivas (classificadas pelos motivos determinantes do crime, previstas nos incisos I e II do $\S 2^{\circ}$, do artigo 121 do Código Penal), objetivas (classificadas pelos meios e formas de execução do crime, previstas nos incisos III e IV $\S 2^{\circ}$ do artigo 121 do Código Penal); ou ontológicas (classificadas pela condição de mulher e policial em serviço, previstas nos incisos VI e VII do artigo 121 do Código Penal) (OLIVEIRA, 2015).

De outro lado, há também o posicionamento segundo o qual o feminicídio teria natureza mista, o que decorreria diretamente da redação do artigo 121, § 2-ㅅ do Código Penal, visto que no caso do primeiro inciso (violência doméstica e familiar), seria de natureza objetiva, ao passo que, no segundo inciso (menosprezo ou discriminação à condição de mulher), seria de natureza subjetiva. Tal entendimento, inclusive, já foi objeto de decisão judicial, como se pode verificar no acórdão no 916484, da $2^{\text {a }}$ Turma Criminal do Tribunal de Justiça do Distrito Federal e dos Territórios, julgado em 28 de janeiro de 2016, oportunidade em que 0 Desembargador relator expressou que, apesar de parte da doutrina, em face da recente inovação legislativa, ter se inclinado a entender que a qualificadora do 
feminicídio é, em qualquer hipótese, de natureza subjetiva, a Lei № 13.104/15 estabeleceu duas causas distintas que caracterizam o feminicídio, a saber: violência doméstica e familiar; menosprezo ou discriminação à condição de mulher (artigo 121, § 2-A, incisos I e II do Código Penal) (TJDFT, 2016).

Neste sentido, arguiu o relator que se o feminicídio for praticado contra a mulher, por exemplo, porque seu agressor não se conforma que ela ocupe um cargo de hierarquia superior ao seu, o motivo do crime é a discriminação e o menosprezo por puro preconceito à condição de mulher. Nesta hipótese, o delito seria de índole subjetiva e, portanto, o preconceito que alimentou a discriminação e o menosprezo não pode caracterizar também o motivo torpe, sob pena de se incorrer em bis in idem (TJDFT, 2016).

Ainda, sob o prisma do entendimento referido, quando o feminicídio for decorrente de violência doméstica e familiar contra a mulher ele teria natureza objetiva, porquanto não se refere aos motivos do crime, uma vez que, para caracterizar o feminicídio no inciso I do $\S 2^{\circ}-\mathrm{A}$, do artigo 121 do Código Penal, bastaria haver a configuração de violência doméstica e familiar descrita no artigo $5^{\circ}$ da Lei no 11.340/06 (TJDFT, 2016).

Também estando ao lado desta corrente César Dario Mariano da Silva ([20-]b), Promotor de Justiça do Estado de São Paulo, entende que a natureza da qualificadora do feminicídio pode ser tanto objetiva (artigo 121, § $2^{\circ}-\mathrm{A}$, inciso I, do Código Penal) quanto subjetiva (artigo 121, § 2ำ A, inciso II, do Código Penal), já que este delito pode envolver violência doméstica e familiar (modo de execução do delito) ou menosprezo ou discriminação à condição de mulher (motivo do delito).

Ressalta-se que a maior controvérsia existente a respeito da natureza da qualificadora do feminicídio recai sobre ser ela objetiva ou subjetiva, razão pela qual será dada maior ênfase a tais posicionamentos a partir deste momento.

Principia-se o discorrer dos dois posicionamentos de maior discussão, a respeito da resolução que se visa, por aquele que entende ser o feminicídio de natureza objetiva.

Para os defensores deste entendimento, a qualificadora em referência possui natureza objetiva, pois, embora a disposição do conceito de violência doméstica e familiar remeta à noção de motivação (em razão da condição de sexo feminino), as definições incorporadas pela Lei ํㅜ 11.340/06 sinalizam contexto de 
violência de gênero, quer dizer, quadro fático-objetivo não atrelado aos motivos determinantes da execução do ilícito (ZANELLA, et al., 2015).

Nesta linha de raciocínio se encontra o posicionamento de Pires (2015, s/p):

\begin{abstract}
A nova qualificadora do feminicídio não constitui o móvel imediato da conduta, isto é, o agente pode ter agido por causa de uma discussão banal com a vítima (motivo fútil) ou por causa da sua possessividade e ciúme excessivo em relação à vítima ou em razão de seu inconformismo com o término do relacionamento afetivo (motivo torpe), para ficar só nesses dois exemplos corriqueiros na lida do Tribunal do Júri, dentre muitos outros. Durante o interrogatório de um réu que tenha praticado um feminicídio, jamais lhe será perguntado se ele cometeu o crime 'por razões de gênero' (ou, 'por razões da condição de sexo feminino'), mas qual o acontecimento, atitude ou episódio do contexto fático-probatório do caso que fez eclodir ou o levou ao ato de violência macabro, ocorrência essa que geralmente constitui algum motivo fútil ou torpe na maioria das vezes, conforme exemplificado.
\end{abstract}

Nesse diapasão, é oportuno fazer referência ao entendimento adotado pela 1a Câmara Criminal do Tribunal de Justiça do Distrito Federal e dos Territórios no acórdão no 904781, julgado em 29 de outubro de 2015, no qual consta que, de acordo com o voto do Desembargador relator, antes da inovação legislativa procedida pela Lei $n=13.104 / 15$ o assassinato da mulher pelo marido era punido como homicídio simples ou, dependendo da motivação, como homicídio qualificado por motivo torpe ou por motivo fútil. Com as alterações trazidas pela lei o crime praticado contra a mulher, decorrente da condição feminina, passou a ser qualificado, motivo pelo qual a inclusão da qualificadora do feminicídio não pode servir como substitutivo das qualificadoras de motivo torpe ou fútil, que são de natureza subjetiva (TJDFT, 2015). O Desembargador ressalta em seu voto a natureza objetiva do feminicídio:

Há que convir que ambas as qualificadoras possam coexistir perfeitamente, porque é diversa a natureza de cada uma: a torpeza continua ligada umbilicalmente à motivação ensejadora da ação homicida, enquanto feminicídio se fará presente toda vez que, objetivamente, se esteja diante de uma situação típica de agressão de homem contra mulher no contexto tradicional de violência doméstica e familiar (TJDFT, 2015).

Portanto, no entendimento da $1^{\circ}$ Turma Criminal do Tribunal de Justiça do Distrito Federal e dos Territórios, a qualificadora do feminicídio possui natureza objetiva e poderia vir a incidir com outra qualificadora de ordem subjetiva, no caso julgado, o motivo torpe (TJDFT, 2015). 
De modo similar a este posicionamento, a 7aㅡ Câmara Criminal do Tribunal de Justiça do Estado de Minas Gerais, no acórdão n 1883493, julgado em 07 de abril de 2016, negou provimento a recurso em sentido estrito interposto pelo réu que tinha por finalidade extirpar uma das qualificadoras do homicídio pelas quais restou incurso. Na ocasião, justificou o réu a inviabilidade de ser julgado por ter agido por motivo torpe e feminicídio em razão de que isso acarretaria em bis in idem. Entretanto, o relator proferiu voto reconhecendo que a coexistência das qualificadoras do motivo torpe e do feminicídio não configuraria o bis in idem, pois tais qualificadoras possuiriam natureza diversa uma da outra, enquanto o homicídio qualificado, pelo motivo torpe, seria de ordem subjetiva, o feminicídio, seria de ordem objetiva (TJMG, 2016).

Corroborando este posicionamento, destaca-se o entendimento do Tribunal de Justiça do Estado do Paraná, que deu provimento ao recurso ministerial no 1.493.533-2RSE, julgado em 19 de maio de 2016, o qual visava a reinclusão da qualificadora do motivo fútil para que o réu fosse pronunciado como incurso na sanção do artigo 121, $§ 2^{\circ}$, incisos II, IV e VII, do Código Penal. O recurso foi provido sob a justificativa de que a qualificadora do motivo fútil possuiria caráter subjetivo, enquanto a do feminicídio possuiria natureza objetiva (TJPR, 2016).

Pode-se constatar na decisão prolatada ao recurso em sentido estrito no 70069881639, julgado em 10 de agosto de 2016, que a 1aㅡ Câmara Criminal do Tribunal de Justiça do Estado do Rio Grande do Sul também compartilha do entendimento que a qualificadora do feminicídio possui natureza objetiva. De acordo com o constante na ementa do julgado:

\footnotetext{
$[\ldots]$

Vindo aos autos dados informativos que apontam para o fato de ter sido o crime cometido em razão da inconformidade do acusado com o término do relacionamento, subsiste a qualificadora do motivo fútil.

Da mesma forma, afigura-se viável aquela atinente ao feminicídio (diga-se, de natureza objetiva), porquanto o delito foi praticado pelo acusado contra sua ex-companheira e, inclusive, no interior da residência dessa, circunstâncias que são indicativas de violência doméstica contra a mulher, na forma do artigo 121, § 20-A, inciso I, do Código Penal [...] (TJRS, 2016).
}

Em contraponto aos posicionamentos já mencionados, há o entendimento de que a qualificadora do feminicídio possuiria natureza subjetiva, diga-se de passagem o entendimento mais adequado na concepção adquirida por meio da presente pesquisa. 
Os defensores da natureza subjetiva do feminicídio aderem à tese de que este delito é qualificado pelos motivos que levaram o agente a cometê-lo, sendo justamente por isso considerado de ordem subjetiva.

\begin{abstract}
A qualificadora do feminicídio é subjetiva, pressupondo motivação especial: o homicídio deve ser cometido contra a mulher por razões da condição de sexo feminino. Mesmo no caso do inciso I do $\S 2^{-}-A$, o fato de a conceituação de violência doméstica e familiar ser um dado objetivo, extraído da lei, não afasta a subjetividade. Isso porque o $\S 2^{\circ}-A$ é apenas um explicativo; a qualificadora está verdadeiramente no inciso $\mathrm{VI}$, que, ao estabelecer que o homicídio se qualifica quando cometido por razões da condição do sexo feminino, deixa evidente que isso ocorre pela motivação, não pelos meios de execução (CUNHA, 2016, p. 66).
\end{abstract}

No mesmo sentido, Barros (2015) dispõe que a qualificadora do feminicídio não se refere às formas de execução do crime, e sim, à motivação delitiva, razão pela qual sustenta que ela é subjetiva.

Fortalecendo essa ideia, assevera Nabuco Filho (2015):

Não parece ser possível que a palavra 'razão', ou 'razões', no plural, tenha outro sentido que não seja "causa, motivo". [...] se o sentido não fosse esse, bastaria ter qualificado o homicídio cometido 'contra mulher'. Nesse caso, abstraindo-se a inconstitucionalidade, o simples fato de a vítima ser mulher, bastaria para a qualificadora. A nova lei não usou essa definição, o que evidencia que não basta a condição de mulher para que se caracterize o feminicídio, é preciso que ela tenha sido morta por ser mulher, que a sua condição tenha sido o motivo do ato de matar. [...] (grifo do autor).

Enfatizando a subjetividade desta qualificadora, Delmanto et al. (2016, p. 683) expõe em relação ao menosprezo ou discriminação à condição de sexo feminino (artigo 121, $2^{\circ}$-A, inciso II, do Código Penal) que "na prática não será fácil demonstrar a ocorrência dessa qualificadora, por ser bastante subjetiva”. A demonstração da qualificadora, nestas circunstâncias, é de mais difícil percepção, pois, diferentemente da constatação do crime cometido no contexto de violência doméstica e familiar que resta claro na observação do caso concreto, o menosprezo ou discriminação está no íntimo do agente.

Compartilhando o entendimento que a qualificadora do feminicídio é subjetiva, Bianchini (2016, p. 216) profere: 
A qualificadora de feminicídio é nitidamente subjetiva. Uma hipótese: mulher usa minissaia. Por esse motivo fático seu marido ou namorado a mata. $\mathrm{E}$ mata-a por uma motivação aberrante, a de presumir que a mulher deve se submeter ao seu gosto ou apreciação moral, como se dela ele tivesse posse, reificando-a, anulando-lhe opções estéticas ou morais, supondo que à mulher não é possível contrariar as vontades do homem. Em motivações equivalentes a essa há uma ofensa à condição do sexo feminino. $O$ sujeito mata em razão da condição do sexo feminino, ou do feminino exercendo, a seu gosto, um modo de ser feminino. Em razão disso, ou seja, em decorrência unicamente disso.

Neste contexto, imprescindível ressaltar alguns entendimentos jurisprudenciais que corroboram esta tese, dentre eles o de Câmaras Criminais do Tribunal de Justiça do Estado do Rio Grande do Sul.

A $3^{\text {a }}$ Câmara Criminal do Tribunal de Justiça do Estado do Rio Grande do Sul manifestou entendimento de que a qualificadora do feminicídio é de natureza subjetiva, conforme pode-se constatar na decisão do recurso em sentido estrito oㅡ 70071042782, julgado em 19 de outubro de 2016, que decidiu pela manutenção da qualificadora do feminicídio e afastamento do motivo torpe. Como apontado na ementa do julgado:

$[\ldots]$

A qualificadora do feminicídio exige que o delito seja praticado em contexto de violência doméstica e familiar ou com menosprezo à condição de mulher, circunstâncias narradas pela denúncia, neste caso, para descrever a qualificadora do motivo torpe, configurando bis in idem. Precedentes (TJRS, 2016).

Em concordância com a jurisprudência mencionada, o recurso em sentido estrito $n^{0}$ 70067112011, julgado em 10 de dezembro de 2015, também pela $3^{\text {a }}$ Câmara Criminal do Tribunal de Justiça do Estado do Rio Grande do Sul, demonstra claramente a natureza subjetiva da qualificadora do feminicídio quando expressa que, no caso julgado, o motivo fútil, consistente no fato de o denunciado não se conformar com o rompimento do namoro com a vítima, preenche as condições para a configuração do feminicídio (TJRS, 2015).

$[\ldots]$

A motivação do crime, todos dizem, teria sido esta. Mas é ela, justamente, que preenche o tipo legal do feminicídio. Se afastado fosse o motivo, a simples condição de ex-namorado não atrairia a qualificadora específica, pois ela exige que haja uma razão da condição do sexo feminino, e esta só pode ser, no caso concreto, a frustração com a rejeição de afeto [...] (TJRS, 2015, grifo nosso). 
Desembargador relator afirma que, seguramente, há bis in idem na dupla imputação de qualificadoras feminicídio e motivo fútil, razão pela qual, para resolver a controvérsia, reconheceu a consunção entre as imputações do motivo fútil e do feminicídio, subsistindo a última (TJRS, 2015).

Sob o mesmo prisma se posicionou a $2^{\text {a }}$ Câmara Criminal do Tribunal de Justiça de Minas Gerais, quando do julgamento do recurso em sentido estrito, acórdão no 0028221, de 22 de setembro de 2016, no qual a Desembargadora relatora destaca que, inobstante a existência de entendimento em sentido diverso, a cumulação entre a qualificadora referente ao motivo fútil e a qualificadora do feminicídio, configuram o vedado bis in idem, pois ambas estão ligadas à motivação do agente para a prática do delito (TJMG, 2016). Acrescenta a julgadora na fundamentação de seu voto:

[...] no caso concreto, ambas se alicerçam no inconformismo do acusado com o término do relacionamento amoroso, ou seja, ambas se referem diretamente à motivação do delito. Dessa forma, o reconhecimento de ambas as citadas qualificadoras agravam duplamente o mesmo fato, o que é vedado (TJMG, 2016).

Gonçalves (2016, p. 164) fortalece o entendimento de que a natureza do feminicídio é subjetiva, o que acarreta a incompatibilidade desta qualificadora com outras qualificadoras de natureza subjetiva, destacando que "[...] para que se tipifique a violência doméstica ou familiar caracterizadora do feminicídio, é inarredável que a agressão tenha como fator determinante o gênero feminino, não bastando que a vítima seja a esposa, a companheira etc".

O autor citado exemplifica que o feminicídio se configura, no caso de o marido matar a esposa, porque ela não quis manter relação sexual ou porque não acatou suas ordens ou, ainda, porque pediu o divórcio. Explica, entretanto, que se ele mata a esposa visando receber o seguro de vida por ela contratado, o delito será qualificado por motivo torpe e não por feminicídio (GONÇALVES, 2016).

Visto isso, se compatível fosse a qualificadora do feminicídio com a do motivo torpe (subjetiva) ou outra de natureza subjetiva, o homicídio contra a mulher não exigiria tais motivações previstas em lei e, no caso citado pelo autor, poderia haver a concomitância entre ambas qualificadoras. Diz-se, portanto, que a qualificadora do feminicídio é de natureza subjetiva, pois refere-se à motivação do agente, senão, não atentando para a questão da constitucionalidade, para que este 
delito se caracterizasse bastaria que o homicídio fosse praticado contra uma mulher, não importando ser, ou não, ele cometido contra a mulher por condições do sexo feminino, sendo, por conseguinte, apenas um femicídio.

Ademais, menciona-se, brevemente, que a consideração da natureza objetiva do feminicídio importa em consequências que, provavelmente, não eram do querer do legislador. Além da violação do princípio ne bis in idem, a qual, por si só, já gera sérias consequências no mundo jurídico, uma vez que imputa ao réu mais de uma punição ao mesmo fato delituoso, também salienta-se que a consideração da natureza objetiva do feminicídio reflete, exclusivamente, na possibilidade da existência do feminicídio privilegiado. Indaga-se: seria relevante que o feminicídio (tipo penal previsto com a finalidade de atenuar o resultado extremo da violência doméstica e familiar contra a mulher, bem como sua discriminação e menosprezo, tipificação decorrente de compromissos assumidos internacionalmente, inclusive, perante a Corte Americana de Direitos Humanos) fosse considerado como cometido por motivo de relevante valor social ou moral?

Evidente que, como dito anteriormente, se o feminicídio fosse qualificadora objetiva, nenhum impedimento existiria para o reconhecimento do privilégio.

Por razões como estas e, principalmente, por se entender que a violência de gênero não é um modo ou meio de execução do delito mas, sim, a motivação da ação homicida, é que se constatou, na presente pesquisa, que o feminicídio deve ser encarado como uma qualificadora de natureza subjetiva do homicídio e, sendo assim, há a impossibilidade de concomitância deste delito com outras qualificadoras subjetivas do homicídio, do contrário se estaria frontalmente violando o ne bis in idem. 


\section{CONCLUSÃO}

Como visto, uma mesma circunstância em direito penal não pode ensejar duas valorações jurídicas em prejuízo ao acusado. Esta é a vedação decorrente do princípio do ne bis in idem, sendo que se propôs buscar nesta pesquisa se é, ou não, adequada a concomitância da qualificadora do feminicídio com outras qualificadoras do homicídio de natureza subjetiva.

De início, é importante reiterar que são compatíveis qualificadoras de ordem subjetiva e objetiva, isto é, o delito de homicídio pode ser qualificado pelos motivos que levaram o agente a cometê-lo (natureza subjetiva), bem como pelos meios por ele utilizados para a execução do crime (natureza objetiva), inocorrendo a violação do ne bis in idem. Entretanto, se elucidou ser adequado entendimento de que não há compatibilidade quando da cumulação de qualificadoras de natureza subjetivas, ou seja, o mesmo homicídio não pode ser qualificado por motivo torpe e por motivo fútil, ambos de natureza subjetiva, sob pena de dupla punição ao agente cometedor do crime.

Destarte, indaga-se: ocorre a violação do ne bis in idem quando da concomitância da qualificadora do feminicídio com qualificadoras subjetivas do homicídio? Para que se possa responder a esta indagação, necessário se fez definir a natureza da qualificadora do feminicídio, a qual, segundo entendimento obtido por meio da presente pesquisa, se compreendeu ser subjetiva.

Primeiramente destaca-se que o artigo 121, § 2ํ, inciso VI, do Código Penal expressa que há feminicídio quando o homicídio for praticado contra a mulher por razões de sexo feminino, referindo no $\S 2^{\circ}-\mathrm{A}$, do mesmo dispositivo, que tais razões são consideradas quando o crime envolve violência doméstica e familiar ou menosprezo ou discriminação à condição de mulher.

Diante do contexto extraído do referido dispositivo legal é possível enfatizar a natureza subjetiva do feminicídio, pois, como visto, esta diz respeito à motivação do agente, que pode ser auferida na menção "contra a mulher por razões de sexo feminino" (razões/motivos), isto é, a configuração do feminicídio está atrelada ao móvel do agente, de forma que esta qualificadora não poderia possuir outra natureza, senão a subjetiva.

Dando continuidade à interpretação do aludido artigo, é possível constatar que nem todo femicídio é um feminicídio, sendo que este é definido pela motivação 
do delito, isto é, para a configuração do feminicídio não basta que a vítima seja mulher, é expressamente previsto, no dispositivo em questão, que o homicídio tenha sido praticado por razões de sexo feminino, o que corrobora ainda mais o entendimento de que a natureza da qualificadora inerente a este delito é subjetiva, pois se está novamente diante da motivação do crime. Ora, um homicídio praticado contra a mulher é um femicídio, um homicídio praticado contra a mulher motivado pela condição do sexo desta é um feminicídio.

É possível auferir a subjetividade do feminicídio também por meio do tratamento dos casos que envolviam violência doméstica e familiar ou menosprezo à condição de mulher, ocorridos antes da promulgação da Lei 13.104/15, os quais, quando qualificados, o eram por motivo torpe ou fútil, ou seja, antes da tipificação do feminicídio, os crimes que hoje configurariam este delito eram qualificados por sua natureza subjetiva, o que reforça ainda mais a conclusão quanto a natureza subjetiva do feminicídio.

Constata-se que, em verdade, a lei do feminicídio não criou uma nova qualificadora, apenas tratou de especificar a qualificadora genérica já existente, qual seja, do motivo torpe, pois o tipo penal genérico não estava sendo o suficiente para coibir e atenuar este delito decorrente da cultura patriarcal e machista existente na sociedade.

Diante das considerações apresentadas, contata-se que a qualificadora do feminicídio é de natureza subjetiva, não podendo esta cumular com outras qualificadoras da mesma natureza, pois, neste caso, haveria a ocorrência da violação do ne bis in idem, o que é vedado na legislação, tendo em vista que não se pode imputar ao agente múltipla condenação ao mesmo fato, do contrário se verificaria excesso na acusação.

Destaca-se que parte da jurisprudência vem decidindo que não há a ocorrência da violação do ne bis in idem quando da cumulação da qualificadora do feminicídio com outra de natureza subjetiva, isto é, considera-se que a qualificadora do feminicídio é de natureza objetiva. Tal consideração está ocasionando punições diversas a acusados que perpetraram idênticas condutas, pois, enquanto parte da jurisprudência vem, equivocadamente, punindo o homicídio contra a mulher por razões do sexo feminino como qualificado por feminicídio e também por motivo torpe ou fútil, outra parte, que defende a natureza subjetiva da qualificadora do feminicídio, 
entende que sua cumulação com outra qualificadora de ordem subjetiva acarretaria na violação do princípio do ne bis in idem.

De qualquer forma, se tem noção da recentidade da qualificadora do feminicídio no sistema penal brasileiro, o que por si só indica a razão das divergências jurisprudenciais e doutrinárias apontadas ao longo da pesquisa.

Em que pese tenha concluído na monografia por ser o feminicídio uma qualificadora de ordem subjetiva, adequado que se deixe claro que o que de fato é relevante é que se pacifique o entendimento quanto a possibilidade - ou não - de concomitância do feminicídio com outras qualificadoras subjetivas do homicídio, em nome, inclusive, da segurança jurídica dos acusados e da necessidade de que todos eles recebam idêntico tratamento.

Certo é que o combate à violência contra a mulher e o resguardo a vida delas não pode se dar à custa do excesso do direito de punir do Estado. Daí a relevância do estudo ora realizado. 


\section{REFERÊNCIAS}

ALBUQUERQUE, Mário David Meyer de. Fundamentos democráticoconstitucionais do Tribunal do Júri. Dissertação apresentada ao Programa de Pós-Graduação em Direito como requisito parcial para a obtenção do título de Mestre em Direito Constitucional. Fortaleza, 2010. Disponível em: <http://www.dominiopublico.gov.br/download/teste/arqs/cp135436.pdf>. Acesso em 3 nov. 2016.

BANDEIRA, Lourdes Maria; ALMEIDA, Tânia Mara Campos. Vinte anos da Convenção de Belém do Pará e a Lei Maria da Penha. Florianópolis: Estudos feministas, 2015. Disponível em:

$<$ https://periodicos.ufsc.br/index.php/ref/article/view/38872>. Acesso em: 18 out. 2016.

BARROS, Francisco Dirceu. Estudo completo do feminicídio. 2015. Disponível em:<http://www.impetus.com.br/artigo/876/estudo-completo-do-feminicidio>. Acesso em: 10 nov. 2016.

BARSTED, Leila Linhares; PITANGUY, Jacqueline. org. O progresso das mulheres no Brasil 2003-2010. Rio de Janeiro: CEPIA; Brasília: ONU Mulheres, 2011.

Disponível em:

<http://onumulheres.org.br/wpcontent/themes/vibecom_onu/pdfs/progresso.pdf> .Acesso em: 22 out. 2016.

BIANCHINI, Alice. A Qualificadora do Feminicídio é de Natureza Objetiva ou Subjetiva?. Revista EMERJ, Rio de Janeiro, v. 19, n. 72, p. 203 - 219, jan. - mar. 2016. Disponível em:

$<$ http://bdjur.sti.jus.br/jspui/bitstream/2011/100621/qualificadora feminicidio naturez a bianchini.pdf>. Acesso em: 12 nov. 2016.

BIANCHINI, Alice; GOMES, Luiz Flávio. FEMINICÍDIO: entenda as questões controvertidas da lei 13.104/2015. [20--]. Disponível em:

$<$ http://institutoavantebrasil.com.br/feminicidio-entenda-as-questoes-controvertidasda-lei-13-1042015/>. Acesso em: 05 de nov. de 2016.

BÍBLIA ONLINE. Gênesis 3:16. Disponível em: <https://www.bibliaonline.com.br/>. Acesso em 05 out. 2016.

BITENCOURT, Cezar Roberto. Tratado de Direito Penal 2 parte especial dos crimes contra a pessoa. 15. ed. São Paulo: Saraiva, 2015. 
BONFIM, Edilson Mougenot. Curso de processo penal. 10. ed. São Paulo: Saraiva, 2015.

BRASIL. Lei no 11.340/2006. 2016a. Disponível em:

<https://www.planalto.gov.br/ccivil_03/_Ato2004-2006/2006/Lei/L11340.htm>. Acesso em: 02 out. 2016.

.Superior Tribunal de Justiça. SÚMULA 536. 2016b. Disponível em: $<\mathrm{http}: /$ www.stj.jus.br/SCON/sumulas/toc.jsp?tipo_visualizacao=RESUMO\&livre=536 $\& b=S U M U \&$ thesaurus=JURIDICO $>$. Acesso em: 05 out. 2016.

.Constituição da República Federativa do Brasil de 1988. 2016c.

Disponível em:

$<$ http://www.planalto.gov.br/ccivil 03/constituicao/constituicaocompilado.htm>. Acesso em: 05 out. 2016.

.Código Penal. 2016d. Disponível em:

<http://www.planalto.gov.br/ccivil_03/decreto-lei/Del2848compilado.htm>. Acesso em: 06 out. 2016.

Lei no 13.142/2016. 2016e. Disponível em:

<http://www.planalto.gov.br/ccivil_03/_Ato2015-2018/2015/Lei/L13142.htm>. Acesso em: 2 nov.2016.

.Código de Processo Penal. 2016f. Disponível em:

<http://www.planalto.gov.br/ccivil_03/decreto-lei/Del3689.htm>. Acesso em 10 de nov. 2016.

CABETTE, Eduardo Luiz Santos. Direito Penal, parte especial I. São Paulo: Saraiva, 2012.

CAMPOS, Carmen Hein de. Feminicídio no Brasil: uma análise crítico-feminista. Revista eletrônica da faculdade de Direito, Programa de Pós-Graduação em ciências Criminais, Pontifícia Universidade Católica do Rio Grande do Sul - PUCRS. Porto Alegre, v. 7., no 1, 2015. Disponível em:

$<$ http://revistaseletronicas.pucrs.br/ojs/index.php/sistemapenaleviolencia/article/view/ 20275>. Acesso em: 05 nov. 2016.

CAPEZ, Fernando. Curso de direito penal. Parte especial dos crimes contra a pessoa a dos crimes contra o sentimento religioso e contra o respeito aos mortos (arts. 121 a 212). 15. ed. São Paulo: Saraiva, 2015. 
COMISSÃO INTERAMERICANA DE DIREITOS HUMANOS. Organização dos Estados Americanos. Relatório anual 2000. Relatório no 54/01. Caso Maria da Penha Maia Fernandes. Brasil, 2001. Disponível em:

$<$ http://www.sbdp.org.br/arquivos/material/299_Relat\%20n.pdf>. Acesso em: 31 out. 2016.

CONVENÇÃO SOBRE A ELIMINAÇÃO DE TODAS AS FORMAS DE DISCRIMINAÇÃO CONTRA A MULHER. CEDAW, 1979. Disponível em: $<$ http://www.compromissoeatitude.org.br/wpcontent/uploads/2012/11/SPM2006_CEDAW_portugues.pdf>. Acesso em: 31 de out. 2016.

COPELLO, Patrícia Laurenzo. Apuentes sobre el feminicídio. Revista de derecho penal y criminologia, 3ํépoca, №. 8, 2012. Disponível em:

$<$ https://dialnet.unirioja.es/servlet/autor?codigo=48859 >. Acesso em: 27 out. 2016.

CORTE INTERAMERICANA DE DERECHOS HUMANOS. Caso Gonzáles y otras, "campo algodonero", VS. México. Sentencia de 16 de noviembre de 2009.

Disponível em: <http://www.corteidh.or.cr/docs/casos/articulos/seriec 205 esp.pdf>. Acesso em 03 nov. 2016.

CUNHA, Rogério Sanches. Manual de direito penal: parte especial (arts. 121 ao 361). 8. ed. Salvador: JusPODVIM, 2016.

DELMANTO, Celso et al. Código Penal comentado. 9. ed. São Paulo: Saraiva, 2016.

Violência doméstica (Lei Maria da Penha): Lei 11.340/2006 comentada artigo por artigo. São Paulo: Revista dos Tribunais, 2007.

DIAS, Maria Berenice. A lei Maria da Penha na justiça: a efetividade da lei 11.340/2006 de combate à violência doméstica e familiar contra a mulher. São Paulo: Revista dos Tribunais, 2008.

ELUF, Luiza Nagib. A paixão no banco dos réus: casos passionais célebres: de Pontes Vesgueiro a Pimenta Neves. 2 ed. São Paulo: Saraiva, 2003.

GAIA, Luciana Garcia. Homicídios passionais: a paixão e sua motivação para o crime. Monografia apresentada ao Centro Universitário Eurípides (UNIVEM) para obtenção do título de Bacharel em Direito. Marília, 2010. 
GALVÃO, Fernando. Direito penal: parte geral. 5. ed. São Paulo: Saraiva, 2013. Disponível em:

$<$ http://aberto.univem.edu.br/bitstream/handle/11077/549/Homic\%C3\%ADdios\%20pa ssionais\%3A\%20a\%20paix\%C3\%A30\%20e\%20sua\%20motiva\%C3\%A7\%C3\%A30 \%20para\%200\%20crime.pdf?sequence=1 >. Acesso em: 28 out. 2016.

GONÇALVES, Victor Eduardo Rios. Direito penal esquematizado: parte especial. 6. ed. São Paulo: Saraiva, 2016.

2012.

Direito penal esquematizado: parte especial. 2. ed. São Paulo: Saraiva,

GRECO, Rogério. Código penal comentado. 14. ed. Rio de Janeiro: Forense, 2014.

Código penal comentado. 5. ed. Niterói: Impetus, 2011.

. Curso de direito penal: parte especial. v. 2: Introdução à teoria geral da parte especial: crimes contra a pessoa. 6. ed. Rio de Janeiro: Impetus, 2009.

HUNGRIA, Nelson. Comentários ao Código Penal. v. 5. 5. ed. Rio de Janeiro: Forense, 1976.

INSTITUTO PATRÍCIA GALVÃO. Feminicídio. Disponível em: $<$ http://www.agenciapatriciagalvao.org.br/dossie/violencias/feminicidio/ $>$. Acesso em 25 out. 2016.

JESUS, Damásio de. Violência contra a mulher: aspectos criminais da Lei no 11.340/2006. São Paulo: Saraiva, 2010.

. Direito penal parte especial. 24. ed. São Paulo: Saraiva, 2001.

Direito Penal. 25. ed. V. 1. São Paulo: Saraiva, 2002.

LEITE, Renata Macêdo; NORONHA, Rosângela Moraes Leite. A violência contra a mulher: herança histórica e reflexos das influências culturais e religiosas. Revista Direito \& Dialogicidade v. 6. Crato, 2015. Disponível em: <http://periodicos.urca.br/ojs/index.php/DirDialog/article/view/959>. Acesso em: 29 out. 2016. 
LIMA, Renato Brasileiro. Legislação Criminal especial comentada. 2. ed. 2014, JusPodivm.

MIRABETE, Julio Fabbrini. Manual de Direito Penal.19. ed. São Paulo: Atlas, 2002.

MIRANDA, Carolina Moreira. Reflexões acerca da tipificação do feminicídio.

Monografia apresentada a Pontifícia Universidade Católica (PUC-Rio) para obtenção do título de Bacharel em Direito. Rio de Janeiro, 2013. Disponível em:

<http://www.maxwell.vrac.puc-rio.br/22487/22487.PDF>. Acesso em: 08 nov. 2016.

NABUCO FILHO, José. Feminicídio. Revista da Faculdade de Direito da Universidade São Judas Tadeu, 2015. Disponível em:

$<$ https://www.usjt.br/revistadireito/numero-3/12-jose-nabuco-galvao-barros-filho.pdf >. Acesso em: 06 de nov. de 2016.

NORONHA, E. Magalhães. Direito penal. 30. ed. São Paulo: Saraiva, 1999.

$\mathrm{NUCCl}$, Guilherme de Souza. Leis penais e processuais penais comentadas. 8 . ed. Rio de Janeiro: Forense, 2014.

Tribunal do júri. 6. ed. Rio de Janeiro: Forense, 2015.

OLIVEIRA, Ana Carolina Gondim de A.; COSTA, Mônica Josy Sousa; SOUSA, Eduardo Sérgio Soares. Feminicídio e violência de gênero: aspectos

sóciojurídicos. TEMA - Revista Eletrônica de Ciências, v. 16, n. 24; 25, 2015.

Disponível em:

<http://revistatema.facisa.edu.br/index.php/revistatema/article/view/236>. Acesso em: 06 out. 2016.

OLIVEIRA, Daniel Bernouli Lucena de. Novas qualificadoras do homicídio e a possibilidade de coexistência com as subjetivas. Disponível em:

$<$ http://www.mpdft.mp.br/portal/index.php/comunicacao-menu/artigos-menu/7890novas-qualificadoras-do-homicidio-e-a-possibilidade-de-coexistencia-com-assubjetivas>. Acesso em: 06 nov. 2016.

PIOVESAN, Flávia. Temas de direitos humanos. 5. ed. São Paulo: Saraiva, 2012.

PIRES, Amom Albernaz. A natureza objetiva da qualificadora do feminicídio e sua quesitação no Tribunal do Júri. 2015. Disponível em: < http://amomalbernaz.jusbrasil.com.br/artigos/172762972/a-natureza-objetiva-daqualificadora-do-feminicidio-e-sua-quesitacao-no-tribunal-do-juri>. Acesso em: 10 nov. 2016. 
PRADO, Luiz Regis. Curso de direito penal. 8. ed. São Paulo: Revista dos Tribunais, 2010.

SABOYA, Keity Mara Ferreira de Souza e. Ne bis in idem: limites jurídicoconstitucionais à persecução penal. Dissertação apresentada ao Programa de Pós - Graduação em Direito, Curso de Mestrado em Direito da Universidade Federal do Rio Grande do Norte como requisito para a obtenção do título de Mestre em Direito. Natal, 2006. Disponível em: $<$ https://repositorio.ufrn.br/ispui/bitstream/123456789/13875/1/KeityMFS.pdf $>$. Acesso em: 05 out. 2016.

SECRETARIA ESPECIAL DE POLÍTICA PARA AS MULHERES. Instrumentos interamericanos de direitos das mulheres. Brasília, 2006. Disponível em: $<$ https://www.google.com.br/search?q=SECRETARIA+ESPECIAL+DE+POL\%C3\%8 DTICAS+PARA+AS+MULHERES.+Instrumentos+interamericanos+de+direitos+das+ mulheres.+Bras\%C3\%ADlia\%2C+2006.\&oq=SECRETARIA+ESPECIAL+DE+POL\% C3\%8DTICAS+PARA+AS+MULHERES.+Instrumentos+interamericanos+de+direitos +das+mulheres.+Bras\%C3\%ADlia\%2C+2006.\&aqs=chrome..69i57.2603j0j8\&sourcei $\mathrm{d}=$ chrome\&ie=UTF8\#q=Instrumentos+interamericanos+de+direitos+das+mulheres $>$. Acesso em 3 nov. 2016.

SENADO FEDERAL. Projeto de Lei do Senado no 292 de 2013. 2013. Disponível em: <http://www25.senado.leg.br/web/atividade/materias/-/materia/113728>. Acesso em: 2 de nov. 2016.

Relatório final da Comissão parlamentar mista de inquérito com a finalidade de investigar a situação da violência contra a mulher no Brasil e apurar denúncias de omissão por parte do poder público com relação à aplicação de instrumentos instituídos em lei para proteger as mulheres em situação de violência, 2013. Disponível em:

$<$ http://www.senado.gov.br/atividade/materia/getPDF.asp?t=130748\& > . Acesso em: 03 nov. 2016.

SILVA, César Dario Mariano da. Primeiras impressões sobre o feminicídio - Lei no 13.104/2015. [20--]b Disponível em:

$<$ http://www.mpsp.mp.br/portal/page/portal/cao criminal/Artigos/Primeiras\%20impres s\%C3\%B5es\%20sobre\%200\%20feminic\%C3\%ADdio.pdf>. Acesso em: 05 nov.2016.

SILVA, Davi André Costa. Compêndio de Direito Penal. Parte geral: Teoria da Norma Penal e Teoria Geral do Delito. 2. Ed. Porto Alegre: Sapiens, 2011. SILVA, Evandro Lins e. 0 salão dos passos perdidos: depoimento ao CPDOC. Rio de Janeiro: Nova Fronteira, 1997. 
SILVA, Raquel Marques da. Evolução histórica da mulher na legislação civil. Porto Alegre, [20--]a. Disponível em: <http://ditizio.ecn.br/adv/txt/ehlc.pdf >. Acesso em 20 out. 2016.

SOUZA, Danielle Peixoto de. Aspectos relevantes do feminicídio na legislação penal brasileira. Monografia apresentada como requisito parcial para a conclusão do Curso de Preparação à Magistratura em nível de especialização. Escola de Magistratura do Paraná. Curitiba, 2015. Disponível em: $<$ http://www.emap.com.br/conteudo/biblioteca/monografias/Carla\%20Souza.pdf $>$. Acesso em: 01 nov. 2016.

SPIELER, Paula; MELO, Carolina de Campos; CUNHA, José Ricardo. Direitos humanos. Rio de Janeiro: Fundação Getúlio Vargas, 2013. Disponível em: $<$ http://docplayer.com.br/7315157-Direitos-humanos-graduacao-2014-2-autorespaula-spieler-carolina-de-campos-melo-e-jose-ricardo-cunha.html>. Acesso em: 29 nov. 2016.

TASSE, Adel el; GOMES, Luiz Flávio. Processo penal IV: júri. São Paulo: Saraiva, 2012.

TRIBUNAL DE JUSTIÇA DO DISTRITO FEDERAL E DOS TERRITÓRIOS. Recurso em sentido estrito no 20150310102700, acórdão no 916484, da 2ª Turma Criminal do Tribunal de Justiça do Distrito Federal e dos Territórios, Relator: Desembargador Souza e Avila, data de julgamento 28 janeiro de 2016. Disponível em:

$<$ http://pesquisajuris.tjdft.jus.br/IndexadorAcordaosweb/sistj?visaold=tjdf.sistj.acorda oeletronico.buscaindexada.apresentacao.VisaoBuscaAcordao\&controladorld=tjdf.sist j.acordaoeletronico.buscaindexada.apresentacao.ControladorBuscaAcordao\&visaoA nterior=tjdf.sistj. acordaoeletronico.buscaindexada. apresentacao.VisaoBuscaAcordao \&nomeDaPagina=resultado\&comando=abrirDadosDoAcordao\&enderecoDoServlet= sistj\&historicoDePaginas=buscaLivre\&quantidadeDeRegistros=20\&baseSelecionada $=$ BASE_ACORDAOS\&numeroDaUltimaPagina $=1$ \&buscalndexada $=1$ \&mostrarPagina SelecaoTipoResultado=false \&totalHits $=1$ \&internet $=1$ \&numeroDoDocumento=91648> . Acesso em: 14 nov. 2016. 


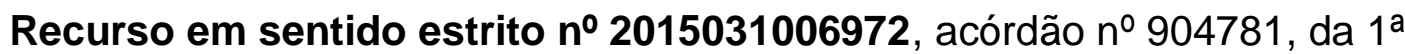
Turma Criminal do Tribunal de Justiça do Distrito Federal e dos Territórios, Relator: Desembargador George Lopes, data de julgamento 29 outubro de 2015. Disponível em: <http://pesquisajuris.tjdft.jus.br/IndexadorAcordaosweb/sistj?visaold=tjdf.sistj.acordaoeletronico.buscaindexada.apresentacao.VisaoBus caAcordao\&controladorld=tjdf.sistj.acordaoeletronico.buscaindexada. apresentacao.C ontroladorBuscaAcordao\&visaoAnterior=tjdf.sistj.acordaoeletronico.buscaindexada.a presentacao. VisaoBuscaAcordao\&nomeDaPagina=resultado\&comando=abrirDados DoAcordao\&enderecoDoServlet=sistj\&historicoDePaginas=buscaLivre\&quantidadeD eRegistros=20\&baseSelecionada=BASE_ACORDAOS\&numeroDaUltimaPagina $=1 \&$ buscalndexada $=1$ \&mostrarPaginaSelecaoTipoResultado=false\&totalHits=1\&internet $=1 \&$ numeroDoDocumento=904781 $>$. Acesso em: 14 nov. 2016 .

TRIBUNAL DE JUSTIÇA DO ESTADO DE MINAS GERAIS. Recurso em sentido estrito no 1.0024.15.188349-3/001, acórdão no 1883493, da 7ª Câmara Criminal do Tribunal de Justiça do Estado de Minas Gerais, Relator: Desembargador Paulo Calmon Nogueira da Gama, data de julgamento: 07 de abril de 2016. Disponível em: <http://www5.tjmg.jus.br/jurisprudencia/pesquisaNumeroCNJEspelhoAcordao.do;jses sionid=4EA4513556DFD0683DB6D13BED8F21D5.juri_node1?numeroRegistro=1\&t otalLinhas $=1$ \&linhasPorPagina $=10$ \&numeroUnico $=1.0024 .15 .188349$ -

3\%2F001\&pesquisaNumeroCNJ=Pesquisar>. Acesso em: 13 nov. 2016.

. Recurso em sentido estrito no 1.0572.15.002822-1/001, acórdão no

0028221 , da 2 ${ }^{\mathrm{a}}$ Câmara Criminal do Tribunal de Justiça do Estado de Minas Gerais, Relator: Desembargadora Beatriz Pinheiro Caires, data de julgamento: 22 de setembro de 2016. Disponível em:

<http://www5.tjmg.jus.br/jurisprudencia/pesquisaNumeroCNJEspelhoAcordao.do;jses sionid=4EA4513556DFD0683DB6D13BED8F21D5. juri_node1 ?numeroRegistro=1\&t otalLinhas $=1$ \&linhasPorPagina $=10$ \&numeroUnico $=1.0572 .15 .002822-$

1\%2F001\&pesquisaNumeroCNJ=Pesquisar > . Acesso em: 14 nov. 2016.

TRIBUNAL DE JUSTIÇA DO ESTADO DO PARANÁ. Recurso em sentido estrito no 1.493.533-2, da 1 Vara Criminal do Tribunal de Justiça do Estado do Paraná, Relator: Desembargador Antonio Loyola Vieira, data de julgamento: 19 de maio de 2016. Disponível em: <http://tjpr.jusbrasil.com.br/jurisprudencia/348821725/recursoem-sentido-estrito-rse-14935332-pr-1493533-2-acordao/inteiro-teor-348821730>. Acesso em 14 nov. 2016. 
TRIBUNAL DE JUSTIÇA DO ESTADO DO RIO GRANDE DO SUL. Recurso em sentido estrito no 70068233998, da 3ª Câmara Criminal do Tribunal de Justiça do Estado do Rio Grande do Sul, Relator: Desembargador João Batista Marques Tovo, data de julgamento: 28 de setembro de 2016. Disponível em:

<http://www.tjrs.jus.br/busca/search?q=cache:www1.tjrs.jus.br/site_php/consulta/con sulta_processo.php\%3Fnome_comarca\%3DTribunal\%2Bde\%2BJusti\%25E7a\%26ve rsao\%3D\%26versao_fonetica\%3D1\%26tipo\%3D1\%26id_comarca\%3D700\%26num _ processo_mask\%3D70068233998\%26num_processo\%3D70068233998\%26codEme nta\%3D6981826+70068233998++++\&proxystylesheet=tjrs_index\&client=tjrs_index\&i $\mathrm{e}=\mathrm{UTF} \& \& \mid \mathrm{r}=$ lang_pt\&site $=$ ementario \&access $=\mathrm{p} \& \mathrm{oe}=\mathrm{UTF} 8 \&$ numProcesso $=70068233$ 998\&comarca=Comarca\%20de\%20Sananduva\&dtJulg=28/09/2016\&relator $=\mathrm{JO} \% \mathrm{C3}$ \%A30\%20Batista\%20Marques\%20Tovo\&aba=juris>. Acesso em: 13 nov. 2016.

. Recurso em sentido estrito no 70069881639 , da $1^{\text {a }}$ Câmara Criminal do Tribunal de Justiça do Estado do Rio Grande do Sul, Relator: Desembargador Honório Gonçalves da Silva Neto, data de julgamento: 10 de agosto de 2016. Disponível em:

<http://www.tjrs.jus.br/busca/search?q=cache:www1.tjrs.jus.br/site_php/consulta/con sulta_processo.php\%3Fnome_comarca\%3DTribunal\%2Bde\%2BJusti\%25E7a\%26ve rsao\%3D\%26versao_fonetica\%3D1\%26tipo\%3D1\%26id_comarca\%3D700\%26num _ processo_mask\%3D70069881639\%26num_processo\%3D70069881639\%26codEme nta\%3D6893522+70069881639++++\&proxystylesheet=tjrs_index\&client=tjrs_index\&i $\mathrm{e}=\mathrm{UTF} \& \& \mid \mathrm{r}=$ lang_pt\&site $=$ ementario \&access $=\mathrm{p} \& \mathrm{oe}=\mathrm{UTF} 8 \&$ numProcesso $=70069881$ 639\&comarca=Comarca\%20 de\%20Santa\%20Maria\&dtJulg=10/08/2016\&relator=Ho n\%C3\%B3rio\%20Gon\%C3\%A7alves\%20da\%20Silva\%20Neto\&aba=juris>. Acesso em: 14 nov. 2016.

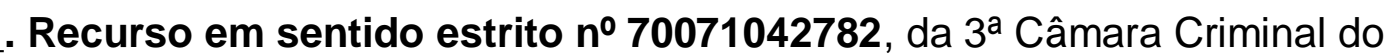
Tribunal de Justiça do Estado do Rio Grande do Sul, Relator: Ingo Wolfgang Sarlet, data de julgamento: 19 de outubro de 2016. Disponível em:

http://www.tjrs.jus.br/busca/search?q=cache:www1.tjrs.jus.br/site_php/consulta/cons ulta_processo.php\%3Fnome_comarca\%3DTribunal\%2Bde\%2BJusti\%25E7a\%26ver sao\%3D\%26versao_fonetica\%3D1\%26tipo\%3D1\%26id_comarca\%3D700\%26num _ processo_mask\%3D70071042782\%26num_processo\%3D70071042782\%26codEme nta\%3D7007235+70071042782++++\&proxystylesheet=tjrs_index\&client=tjrs_index\&i $\mathrm{e}=U T F 8 \& \mid r=$ lang_pt $\&$ site $=$ ementario \&access $=p \& o e=U T F 8 \&$ numProcesso $=70071042$ $782 \&$ comarca $=$ Comarca $\% 20$ de $\% 20$ Erechim\&dtJulg=19/10/2016\&relator=Ingo\%20W olfgang\%20Sarlet\&aba=juris> . Acesso em: 15 nov. 16. 
Recurso em sentido estrito no 70067112011, da 3ª Câmara Criminal do Tribunal de Justiça do Estado do Rio Grande do Sul, Relator: João Batista Marques Tovo, data de julgamento: 10 de dezembro de 2015. Disponível em: $<$ http://www.tjrs.jus.br/busca/search?q=cache:www1.tjrs.jus.br/site_php/consulta/con sulta_processo.php\%3Fnome_comarca\%3DTribunal\%2Bde\%2BJusti\%25E7a\%26ve rsao\%3D\%26versao_fonetica\%3D1\%26tipo\%3D1\%26id_comarca\%3D700\%26num _ processo_mask\%3D70067112011\%26num_processo\%3D70067112011\%26codEme nta\%3D6601493+70067112011++++\&proxystylesheet=tjrs_index\&client=tjrs_index\&i $\mathrm{e}=U T F 8 \& \mid r=$ lang_pt\&site $=$ ementario\&access $=p \& o e=U T F 8 \&$ numProcesso $=70067112$ 011\&comarca=Comarca\%20de\%20S\%C3\%A30\%20Marcos\&dtJulg=10/12/2015\&rel ator=Jo\%C3\%A30\%20Batista\%20Marques\%20Tovo\&aba=juris>. Acesso em 14 nov. 2016.

ZANELLA, Everton Luiz et al. FEMINICÍDIO: considerações iniciais. Centro de Apoio Operacional Criminal do Ministério Público do Estado de São Paulo. São Paulo, 2015. Disponível em:

<http://www.mpsp.mp.br/portal/page/portal/cao_criminal/Artigos/FEMINIC\%C3\%8DD 10\%20-\%20Considera\%C3\%A7\%C3\%B5es\%20Iniciais\%20-\%20CAOCrim\%20\%20Texto\%20Final.pdf>. Acesso em: 10 nov. 2016.

ZANELLATO FILHO, Paulo José. A (in) constitucionalidade da pena de perdimento aduaneira. Dissertação apresentada como requisito parcial à obtenção do grau de Mestre em Direito, no curso de Pós - Graduação em Direito da Universidade Federal do Paraná. Curitiba, 2015. Disponível em:

$<$ http://acervodigital.ufpr.br/handle/1884/40845>. Acesso em: 10 nov. 2016. 